\title{
Article \\ Glacial Ripping in Sedimentary Rocks: Loch Eriboll, NW Scotland
}

\author{
Adrian M. Hall ${ }^{1, * \mathbb{D}}$, Hannah Mathers ${ }^{2} \mathbb{D}$ and Maarten Krabbendam ${ }^{3}$ \\ 1 Department of Physical Geography, Stockholm University, SE-106 91 Stockholm, Sweden \\ 2 School of Geographical \& Earth Sciences, University of Glasgow, Glasgow G12 8QQ, UK; \\ Hannah.Mathers@glasgow.ac.uk \\ 3 British Geological Survey, Edinburgh EH14 4AP, UK; mkrab@bgs.ac.uk \\ * Correspondence: adrian.hall@natgeo.su.se
}

Citation: Hall, A.M.; Mathers, H.; Krabbendam, M. Glacial Ripping in Sedimentary Rocks: Loch Eriboll, NW Scotland. Geosciences 2021, 11, 232. https://doi.org/10.3390/ geosciences 11060232

Academic Editors: Angelos

G. Maravelis and

Jesus Martinez-Frias

Received: 20 April 2021

Accepted: 27 May 2021

Published: 29 May 2021

Publisher's Note: MDPI stays neutral with regard to jurisdictional claims in published maps and institutional affiliations.

Copyright: (c) 2021 by the authors. Licensee MDPI, Basel, Switzerland. This article is an open access article distributed under the terms and conditions of the Creative Commons Attribution (CC BY) license (https:// creativecommons.org/licenses/by/ $4.0 /)$.

\begin{abstract}
Glacial ripping is a newly recognized process sequence in which subglacial erosion is triggered by groundwater overpressure. Investigations in gneiss terrain in lowland Sweden indicate that ripping involves three stages of (i) hydraulic jacking, (ii) rock disruption under subglacial traction, and (iii) glacial transport of rock blocks. Evidence for each stage includes, respectively, dilated fractures with sediment fills, disintegrated roches moutonnées, and boulder spreads. Here, we ask: can glacial ripping also occur in sedimentary rocks, and, if so, what are its effects? The case study area is in hard, thinly bedded, gently dipping Cambrian quartz-arenites at Loch Eriboll, NW Scotland. Field surveys reveal dilated, sediment filled, bedding-parallel fractures, open joints, and brecciated zones, interpreted as markers for pervasive, shallow penetration of the quartz-arenite by water at overpressure. Other features, including disintegrated rock surfaces, boulder spreads, and monomict rubble tills, indicate glacial disruption and short distance subglacial transport. The field results together with cosmogenic isotope ages indicate that glacial ripping operated with high impact close to the former ice margin at Loch Eriboll at 17.6-16.5 ka. Glacial ripping thus can operate effectively in bedded, hard sedimentary rocks, and the accompanying brecciation is significantif not dominant-in till formation. Candidate markers for glacial ripping are identified in other sedimentary terrains in former glaciated areas of the Northern Hemisphere.
\end{abstract}

Keywords: glacial ripping; groundwater overpressure; breccia; rubble till; Cambrian quartz-arenite

\section{Introduction}

Recent work in lowland Sweden recognized a new process of erosion, termed glacial ripping, that operated beneath the last Fennoscandian Ice Sheet (FIS) [1]. Ripping involved a sequence of process steps that comprise (i) hydraulic jacking and opening of subhorizontal fractures, (ii) consequent disruption of the near-surface rock mass under subglacial traction, and (iii) transport and deposition beneath the ice sheet. Glacial ripping operated with high effectiveness in Sweden, affecting large areas to median depths of 1-4 m. Ripping was triggered by build-up of groundwater overpressure in the shallow subsurface in the ice marginal zone of the retreating FIS [1,2].

In this paper, we consider if and how glacial ripping may operate in hard sedimentary rocks. We apply a checklist of features identified in basement gneisses in Sweden as markers for glacial ripping to test if similar features developed in sedimentary rocks in Scotland beneath the last British Irish Ice Sheet (BIIS). The study area is in Cambrian quartzite at Loch Eriboll, NW Scotland (Figure 1). Our field surveys identified many candidate features for groundwater overpressure and glacial ripping, but important differences exist which reflect the distinctive structure of the Eriboll quartz-arenite and the local glaciological conditions. Comparisons with other glaciated sedimentary bedrock terrains suggest that glacial ripping operated widely beneath ice sheets during the Pleistocene. 

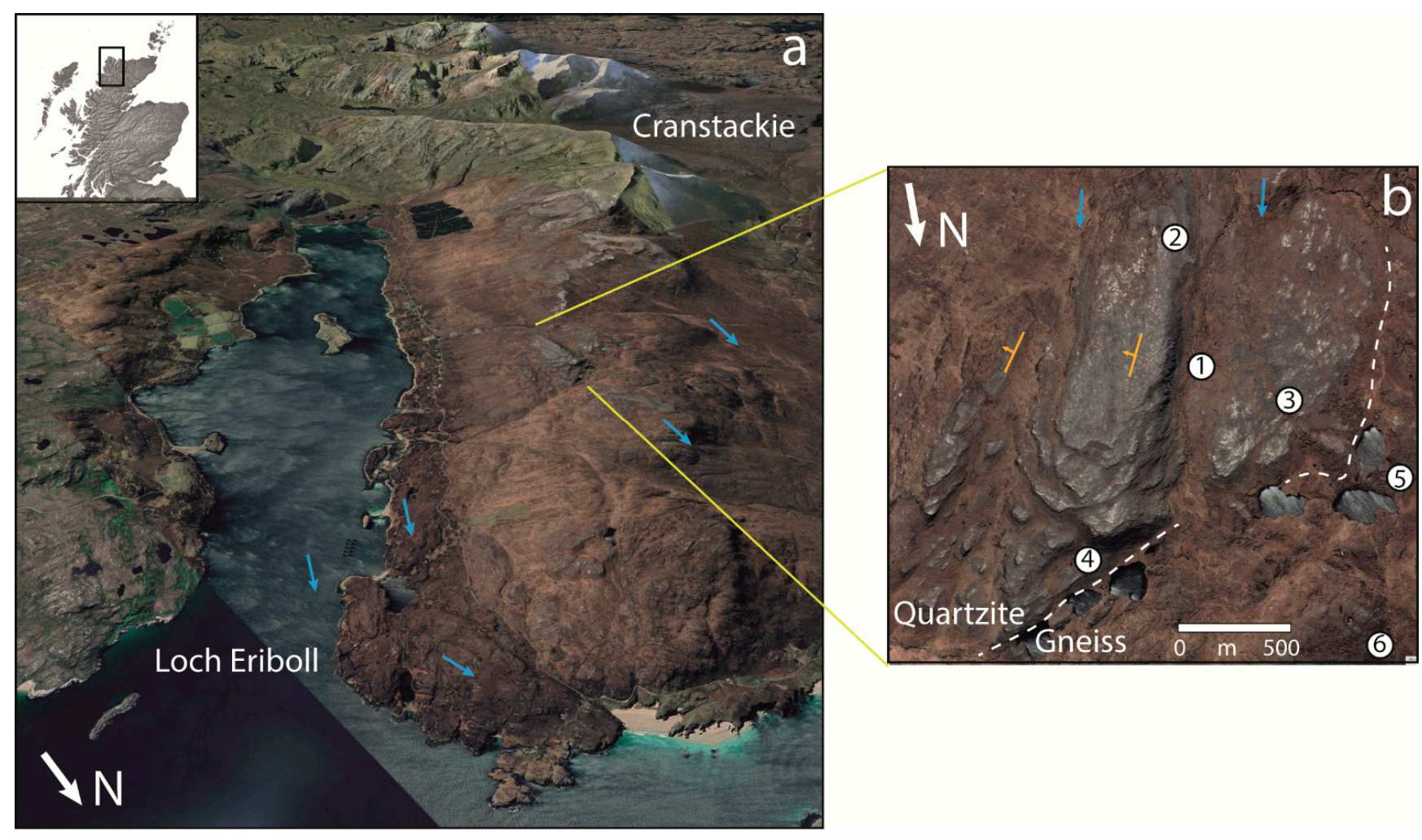

Figure 1. Topography and landforms around Loch Eriboll, NW Highlands. Images @ CNS/Airbus, Google, Maxar Technologies. (a) Location and topography. Blue arrows indicate directions of ice flow. (b) Structural landforms at Hill 314 (Figure 2c). 1. Strike-parallel valley, deepened by glacial erosion. 2. Flank cliff facing up dip, with rounded edge. 3. Backslope, with glacially abraded surface. 4. Stepped face after lee-side glacial plucking. 5. Shallow rock basin developed after excavation of weathered gneiss on the sub-Cambrian unconformity. 6. Low gneiss dome. Dashed white line indicates the line of unconformity between the Lewisian gneiss and the overlying Basal Quartzite.

\section{Geology and Glacial Geomorphology}

Loch Eriboll is a NNE-SSW trending sea loch that occupies a $15 \mathrm{~km}$ long glacially over-deepened valley in the north-west Highlands, Scotland (Figure 1a). The western flank of the loch rises as a gently inclined, sub-planar surface that emerges from below sea level and extends to the summit of Cranstackie ( $802 \mathrm{~m}$ above sea level (a.s.l.). The topographic surface is an expression of structural control imposed by the dip of the Cambrian quartzarenite strata and of the near-planar unconformity on the underlying Precambrian gneisses of the Lewisian gneiss complex.

\subsection{Geology}

The Cambrian Eriboll Formation in the NW Highlands was deposited unconformably upon the Archaean-Palaeoproterozoic Lewisian Gneiss. This unconformity is remarkably flat and is a fragment of the Great Unconformity of Laurentia. The Eriboll Formation is overlain by the very thin (c. $30 \mathrm{~m}$ ) An-t-Sron Formation (not shown on the map), followed by the thicker units of Ordovician limestones and dolostones of the Durness group (e.g., [3]).

The Eriboll Formation comprises two members: the Basal Quartzite Member and the Pipe Rock Member [4]. In this study, attention was focused on the lower, 75-125 m thick Basal Quartzite, comprising cross-bedded quartz-arenite (the unit name was historic when the term quartzite was also applied to sedimentary rocks with very high quartz content) (Figure 2a). At Eriboll, the unconformity and the quartz-arenite beds dip $10-15^{\circ}$ to the ESE and strike to ENE [5], more or less parallel to the long axis of the Loch. In the study area, the quartz-arenite comprises mainly quartz, with $5-10 \%$ feldspar grains. The grains are tightly packed with little matrix [6]. Porosity is mostly very low $(<1 \%)$ [5]. The Basal 
Quartzite in NW Scotland is very hard [7] with a median bed thickness of $0.16 \mathrm{~m}$ and a typical range in joint spacing of $0.13-0.47 \mathrm{~m}$ [8]. Individual quartz-arenite beds are rarely $>1.5 \mathrm{~m}$ thick. Vertical fracture spacing and length follow power laws across scales [9], with wider spacing of vertical fractures in thicker beds (Figure $2 b$ ). Long, straight vertical fractures form dominantly orthogonal joint patterns on rock pavements [5].
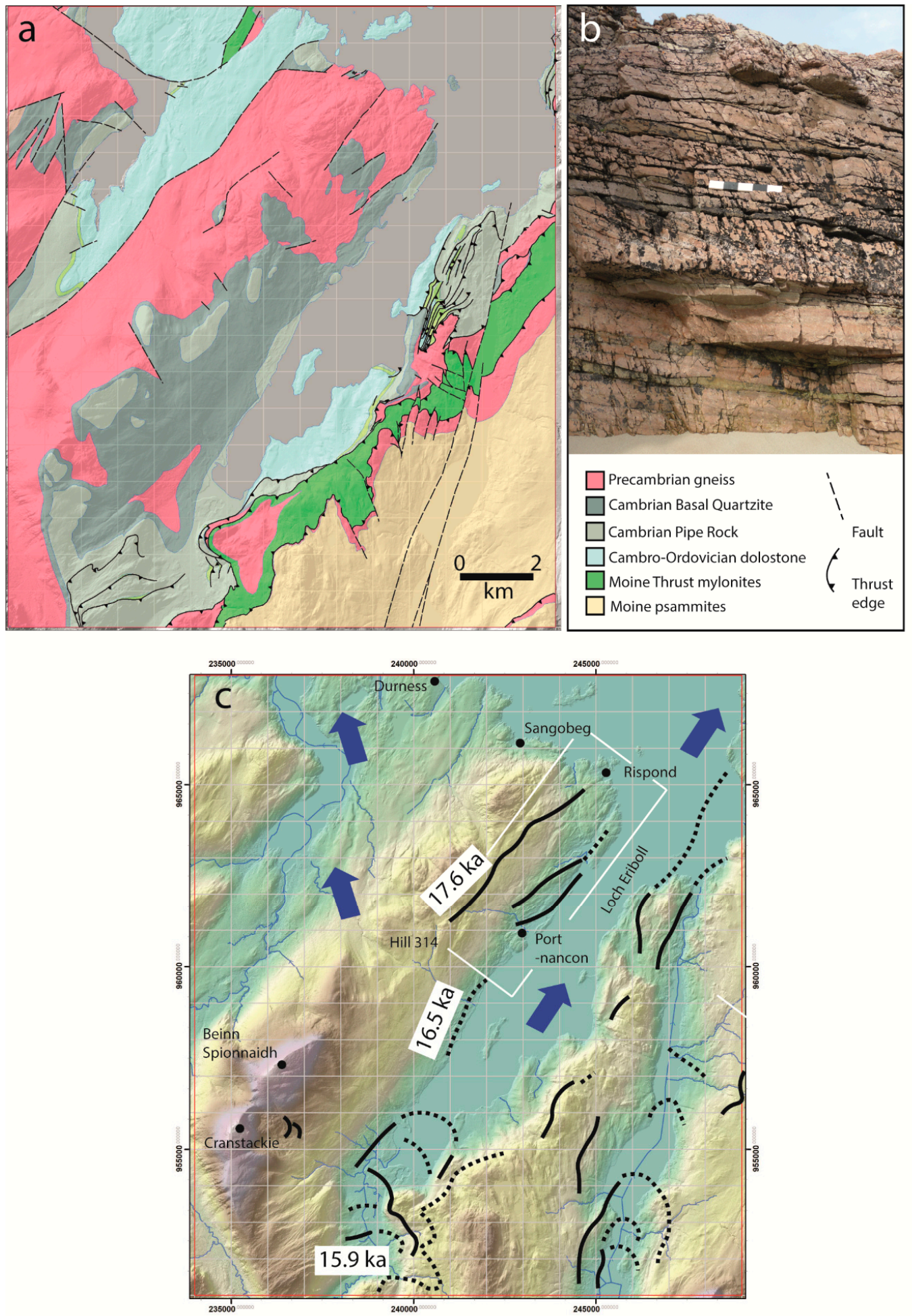

Figure 2. Geology and geomorphology. (a) Geology and relief based on BGS maps. (b) Cambrian Basal Quartzite at Sangobeg (Figure 1c). The scale bar is $0.5 \mathrm{~m}$ long. (c) Topography, ice flow, and dated ice limits. 


\subsection{Ice Dynamics}

During the Pleistocene, the BIIS built up over the mountains of the north-west Highlands, discharging mainly westward into the Minch Ice Stream and reaching maximum limits close the edge of the continental shelf [10]. The Loch Eriboll catchment fed ice northward onto the shelf along the eastern edge of this ice stream in the West Orkney Basin. This flow pattern was repeated during the last Late Devensian $(\sim 31-11.7 \mathrm{ka})$ glaciation. During and after the Last Local Glacial Maximum (LLGM), glacier ice overtopped the ridge that extends $\mathrm{N}$ from Cranstackie, flowing to the NNW (Figure 1a). Deglaciation was underway by $23 \mathrm{ka}$ [11], and a terrestrial ice margin stood at the entrance to Loch Eriboll at $\sim 17.6 \mathrm{ka}$ [12]. Moraine ridges and meltwater channel systems found close to present sea level at Portnancon relate to a younger ice margin that dates from $~ 16.5 \mathrm{ka}$ [12]. Thinning of the Eriboll glacier led to increasing topographic control over ice flow. Late ice flow was to the NNE, along the valley axis and subparallel to the strike of the quartz-arenite.

The homoclinal structure of the uniformly eastward dipping quartz-arenite strata is associated with simple structural landforms (Figure 1b). Low cuestas are developed in thick beds of quartz-arenite, with cliffs oriented along strike, facing mainly upslope, and long backslopes following dip, facing downslope eastward (Figure 1b). The structural forms were shaped by glacial erosion. Elongate strike-parallel ridges have blunt but rounded SSW-facing stoss side and flank faces, whereas NNE-facing lee faces display stepped cliffs with sharp edges. East-dipping dip slopes show extensive, smooth rock pavements developed on bedding plane surfaces that carry a range of glacial microforms developed through abrasion, including polish, striae, and crescentic fractures. Shallow valleys and depressions are developed along strike. This assemblage of structural and glacial forms is typical for Cambrian quartz-arenite in other parts of the NW Highlands $[7,8]$.

\section{Methods}

Previous work in Precambrian gneiss terrain of eastern Sweden identified markers for hydraulic jacking, rock disruption, and boulder transport, the components of glacial ripping [1,2]. Here, we present a checklist of potential marker features recognised in Sweden (Figure 3). We applied this checklist in a search at Loch Eriboll for similar markers of jacking (J1-J5), disruption (D1-D6), and transport and deposition (T1-T6) (Table 1).

Hydraulic jacking beneath glacier ice involves dilation of horizontal fractures under groundwater overpressure; its operation is indicated by opened horizontal fractures and by the filling of open fractures by sediment and rock. In sedimentary rocks, potential evidence for jacking is provided by dilation and sediment fill along bedding planes. Disruption involves the disintegration of the shallow rock mass, typically observed in a roche moutonnée or other rock hill. In quartz-arenite, disruption is indicated by opening of vertical joints and horizontal bedding planes, the brecciation of parts of the rock mass and the onset of differential movement between blocks. Transport involves movement under traction of rock blocks as boulders or rafts at the glacier bed. Extensive covers of locally derived, angular boulders are termed boulder spreads [1]. Additionally, other features are observed on abraded quartz-arenite pavements which are potentially attributable to glacial ripping. These features include sockets and décollement surfaces from which blocks and sheets of quartz-arenite were removed.

Further potential evidence for disruption and transport during glacial ripping is provided by brecciation of the rock mass at shallow depth and the development of rubble tills (akin to the immature tills described by Croot and Sims, 1996). The breccias are described in terms of appearance, disaggregation, texture, and matrix-fill. Crackle and mosaic breccias comprise angular clasts that still fit together with no or minor displacement, indicating formation through in situ disaggregation of the rock mass [17]. In crackle breccia, the void space between clasts is $<20 \%$ of the rock volume, whereas, in mosaic breccia, it is $>20 \%$. Rubble breccias also show $>20 \%$ void space, but the original structural fabric is more strongly disrupted such that few blocks can be fitted together [18]. Texture refers to size, shape, and arrangement of the discrete blocks in the breccia. Arrangement refers to the 
degree of fragmentation, separation, and rotation of blocks seen in plan and section. The rubble tills are described in terms of appearance, texture, clast size, and compaction [19].

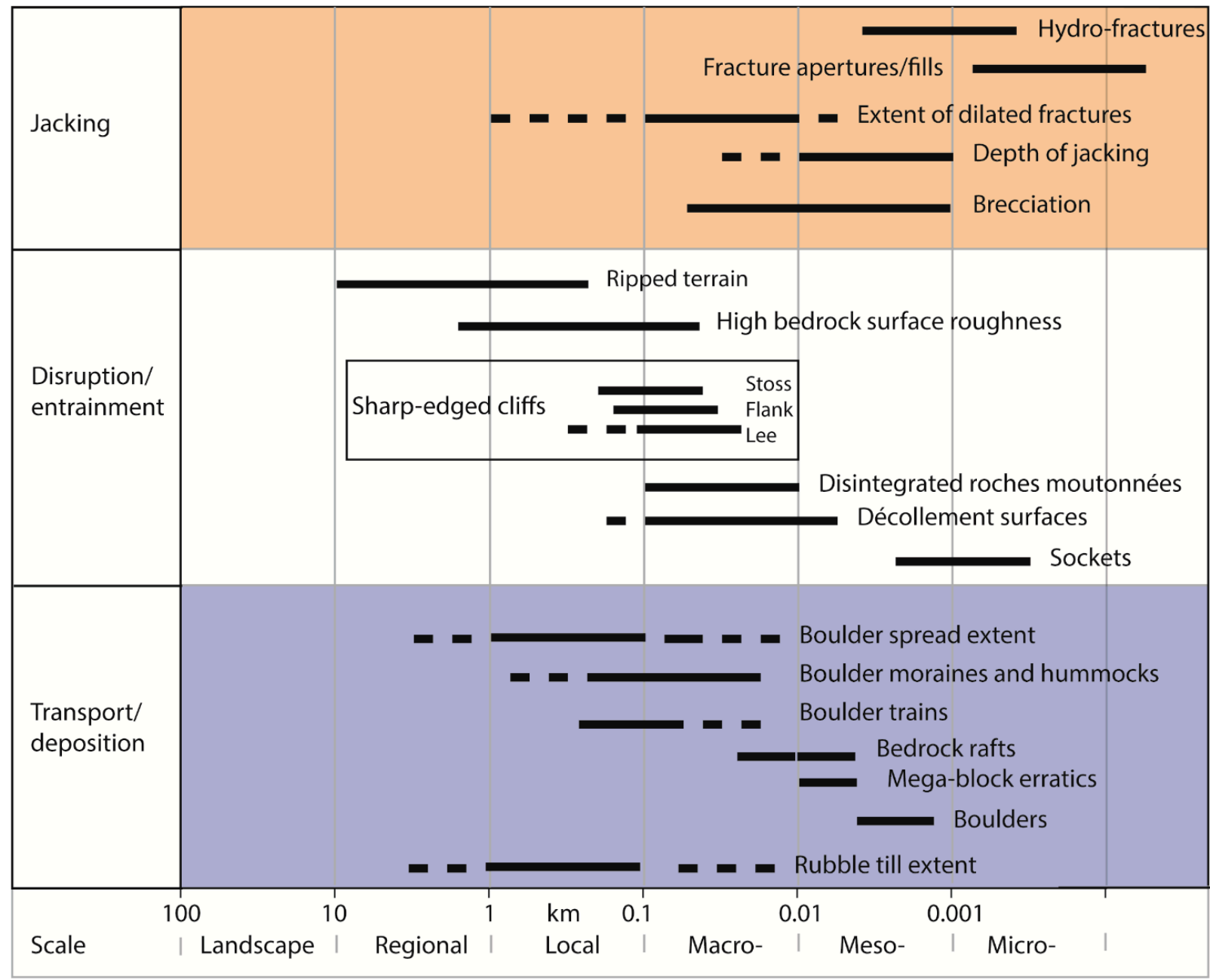

Figure 3. Features at different scales associated with groundwater overpressure and the three steps in the glacial ripping process. Solid lines depict modal scales; dashed lines indicate scale range. Each feature is described in Table 1.

Table 1. Checklist for ice-sheet bed features indicative of the operation of subglacial groundwater overpressure and the glacial ripping process sequence in lowland Sweden.

\begin{tabular}{|c|c|c|c|c|}
\hline Process Step & Criterion & Feature & Definition & $\begin{array}{l}\text { Additional } \\
\text { References }\end{array}$ \\
\hline \multirow[t]{5}{*}{ Jacking } & $\mathrm{J} 1$ & Dilated fracture & $\begin{array}{l}\text { Existing rock fracture opened under groundwater } \\
\text { at overpressure }\end{array}$ & \multirow{5}{*}{ [2] } \\
\hline & $\mathrm{J} 2$ & Brecciation & $\begin{array}{l}\text { Disintegration of the near-surface rock mass into angular } \\
\text { fragments with little or no transport }\end{array}$ & \\
\hline & $\mathrm{J} 3$ & Hydro-fracture & New fracture formed under groundwater overpressure & \\
\hline & $\mathrm{J} 4$ & $\begin{array}{l}\text { Beam failure } \\
\text { fracture }\end{array}$ & $\begin{array}{l}\text { New vertical fracture formed as rock beams crack whilst } \\
\text { jacked under ice loading }\end{array}$ & \\
\hline & J5 & Fracture fill & Clastic dykes and sills filling dilated fractures & \\
\hline \multirow[t]{3}{*}{ Disruption } & D1 & Ripped terrain & $\begin{array}{l}\text { Rock terrain showing high rock surface roughness, } \\
\text { displaced blocks, and angular rock forms }\end{array}$ & \multirow[t]{3}{*}{ [13] } \\
\hline & D2 & Cliff & $\begin{array}{l}\text { Sites of tearaway where rock sheets or blocks were lost } \\
\text { from the stoss, flank and lee sides of rock hills }\end{array}$ & \\
\hline & D3 & $\begin{array}{l}\text { Décollement } \\
\text { surface }\end{array}$ & $\begin{array}{l}\text { Basal failure plane beneath mobilised or missing } \\
\text { rock sheets }\end{array}$ & \\
\hline
\end{tabular}


Table 1. Cont.

\begin{tabular}{|c|c|c|c|c|}
\hline Process Step & Criterion & Feature & Definition & $\begin{array}{l}\text { Additional } \\
\text { References }\end{array}$ \\
\hline & D4 & $\begin{array}{l}\text { Disintegrated } \\
\text { roches moutonnées }\end{array}$ & Roches moutonnées opened up under subglacial traction & \\
\hline & D5 & Fracture cave & $\begin{array}{l}\text { Fracture-bounded cave developed from pull-apart of the } \\
\text { rock mass }\end{array}$ & \\
\hline & D6 & Socket & Site of rock block removal by moving glacier ice & [13] \\
\hline \multirow[t]{6}{*}{$\begin{array}{l}\text { Transport and } \\
\text { deposition }\end{array}$} & $\mathrm{T} 1$ & Boulder spread & $\begin{array}{l}\text { Dense surface concentration of angular, locally derived, } \\
\text { and glacially transported boulders }\end{array}$ & \\
\hline & $\mathrm{T} 2$ & Boulder moraine & $\begin{array}{l}\text { Ridge or hummock composed largely of angular } \\
\text { boulders and set within boulder spreads }\end{array}$ & \\
\hline & T3 & Bedrock raft & $\begin{array}{l}\text { A largely intact mass of bedrock moved by ice from its } \\
\text { original position }\end{array}$ & \\
\hline & $\mathrm{T} 4$ & Boulder train & $\begin{array}{l}\text { A swath or trail of boulders found down-ice of the } \\
\text { source outcrop }\end{array}$ & \\
\hline & $\mathrm{T} 5$ & Megaclast erratic & Rock block with $\mathrm{b}$ axis $>4.1 \mathrm{~m}$ & {$[14]$} \\
\hline & T6 & Rubble till & $\begin{array}{l}\text { Immature, poorly sorted subglacial deposit showing } \\
\text { high clast angularity and low matrix fines content, } \\
\text { dominated by clasts of local bedrock (monomict) }\end{array}$ & {$[15,16]$} \\
\hline
\end{tabular}

Mapping was focused on establishing the distributions of potential markers for jacking, disruption, and transport in a detailed study area between Rispond and Portnancon (Figure 1c). This area has extensive exposure of quartz-arenite backslopes and cliff faces and includes several small quarries from which quartz-arenite rubble is extracted.

\section{Results}

\subsection{Precursor Glacial Forms}

The simple homoclinal structure of the quartz-arenite exerted a strong control over landforms of glacial erosion at Loch Eriboll (Figure 1b). The main features are summarized in Figure 4a. Strike-parallel valleys, some occupied by rock-cut meltwater channels, separate homoclinal ridges. Stoss and flank slopes on the ridges are blunt with rounded edges, whereas lee slopes are stepped with mainly sharp edges (Figure 4b). The quartz-arenite backslopes show extensive rock pavements developed on bedding plane surfaces, where joints remain tight. The pavements carry a range of glacial microforms developed through abrasion, including polish, striae, and crescentic fractures (Figure $4 c, d$ ). The quartz-arenite ridges are interpreted as large roches moutonnées, formed after abrasion of top surfaces and edges, combined with lee-side plucking of blocks. The hills, however, have distinctive elongate long profiles and asymmetric cross profiles that reflect structural controls.

At Hill 314 (Figure 1b), glacially streamlined quartz-arenite ridges are oriented to NNW and carry extensive, striated backslope pavements with stepped lee-side slopes that lack large debris accumulations below. The ridges were eroded when ice was of sufficient thickness to flow across the watershed W of Loch Eriboll (Figure 1a). Striated rock pavements found on Cambrian quartz-arenite in other parts of the NW Highlands developed beneath thick, warm-based ice at the LLGM or during early deglaciation [20]. Hence, the homoclinal ridges with their abraded backslopes and asymmetric longitudinal forms likely mainly developed before the latest stages of deglaciation when ice flowed NNE parallel to Loch Eriboll. The features summarized in Figure 4a are termed precursor glacial forms, formed without glacial ripping. They are similar those recorded elsewhere on the same lithology [7].

On the neighbouring Precambrian gneisses, glacial erosion removed shallow saprolite from the re-exposed surface of the sub-Cambrian unconformity to form shallow rock basins (Figure 1b). Low, rounded whalebacks on the gneiss contrast with the more rectilinear forms on the quartz-arenite (Figure 4e). At Rispond, rock basins and fracture-aligned trenches are set among low whalebacks and roches moutonnées with abraded upper sur- 
faces [21]. Whalebacks and roches moutonnées represent precursor glacial forms developed on Lewisian gneiss.
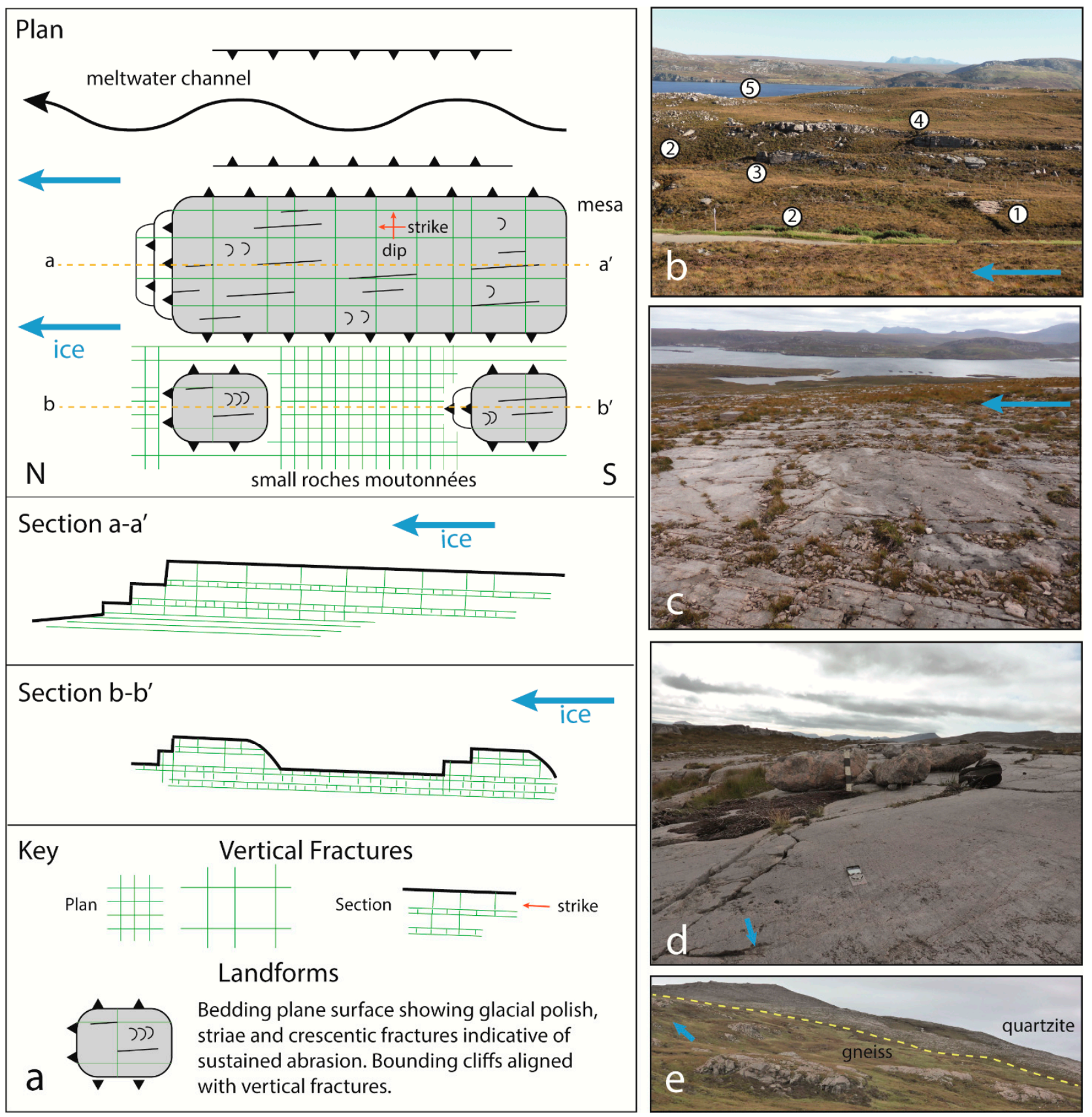

Figure 4. Plan and section model of the main structural and precursor glacial landforms developed in Cambrian quartzarenite at Loch Eriboll. (a) Model of glacial erosion forms in relation to quartz-arenite structure and ice flow direction. (b) View looking SE from British National Grid reference NC 438633 and down dip across structurally controlled homoclinal ridges with typical glacial erosion forms. (1) Gneiss unconformity surface at the base of the quartz-arenite. Plane of unconformity indicated by dashed line. (2) Meltwater channels. (3) Small cliff on plucked lee side of ridge. (4) Lateral cliff in thick quartz-arenite bed on edge of homoclinal ridge. (5) Roche moutonnée. (c) View down dip across an extensive quartz-arenite pavement on Hill 314. (d) Detail of bedding plane surface at NC 431638 viewed along strike showing striated surface and gneiss erratic boulders. Scale bar is $0.5 \mathrm{~m}$ long. (e) Different terrains on Precambrian gneiss and Cambrian quartz-arenite, with the line of unconformity shown. Boulder spreads are confined to the quartz-arenite. View $\mathrm{N}$ from Hill 314. 
At Loch Eriboll, the precursor glacial forms in quartz-arenite show later damage. Damage involves fracturing, brecciation, and block detachment and includes several candidate markers for jacking, disruption, and transport that are recognized in Sweden (Table 1). Thus, the accumulated damage on the quartz-arenite precursor glacial forms may include evidence for glacial ripping. The damage to precursor forms in neighbouring gneiss terrain is much more restricted. The precursor forms and the in situ quartz-arenite bedrock (Figure $2 b$ ) act as our controls for the identification of damage and disruption.

\subsection{Fracture Dilation and Formation}

Many quartz-arenite surfaces at Loch Eriboll show dilated joints and bedding planes in plan and section (Figure 5). Open subvertical joints with apertures of 2-35 cm are observed on abraded quartz-arenite pavements, picked out where peaty soil fills the open joints and contrasts with the bright, grey surface of the quartz-arenite (Figure 6). Bedding plane apertures are smaller $(2-5 \mathrm{~cm})$, locally reaching $30 \mathrm{~cm}$ (Figure 6a). On flank cliffs, open bedding planes and joints occur mainly in the upper $0.5-2.5 \mathrm{~m}$ of the section.

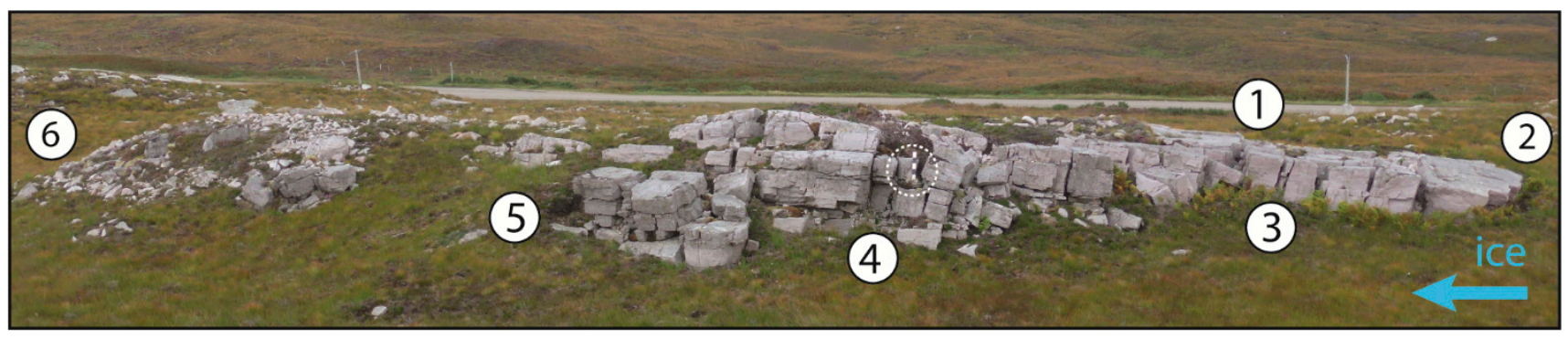

Figure 5. Fracture dilation and formation. View down-dip across a disrupted $\sim 100 \mathrm{~m}$ long roche moutonnée (D4) at NC 4380 6327. The scale bar (circled) is $0.5 \mathrm{~m}$ long. (1) Abraded top surface, (2) stoss side block loss (D6), (3) dilated joints (J1), (4) dilated bedding planes and joints (J1), (5) sites of block loss from flank and lee of hill (D2 and D6), (6) tail of rubble till (T6). For criterion codes, see Table 1.

Open joints show mainly void space with limited accumulation of rock fragments and sediment. While some vertical joints maintain constant apertures with depth, others taper downwards. Open bedding planes may also show void space between in situ or rotated rock fragments derived from disintegration of bedding plane surfaces or of thin intercalated beds. Alternatively, dilated bedding planes may be filled by clastic sills [22] of pebble gravel, massive and laminated sand, rubble breccia, or diamicton (Figure 7).

Open bedding planes and joints represent the dilation of existing fractures. New fractures are also found that transect existing fracture sets. Cracking of quartz-arenite slabs in abraded pavements is widespread (Figure $6 \mathrm{~b}$ ). In plan view, the cracks transect joints of the pre-existing orthogonal fracture network and show irregular traces. Blocks of quartz-arenite between branching cracks generally remain flush with surrounding abraded surfaces but are also seen to be displaced downwards or, less commonly, upwards by 2-10 cm. In section, some cracks terminate downwards (Figure $6 \mathrm{c}$ ) and thus propagated from the slab surface.

A second type of new fracture is seen in the section where brecciated zones occur beneath relatively undisturbed beds. Intense brecciation typically follows thin beds of quartz-arenite (Figure 8a). Thin, closely jointed beds of quartz-arenite act as conduits for water flow from the adjacent walls of rock-cut meltwater channels (Figure 8b). The rotation and the displacement of quartz-arenite fragments within the breccias indicate that water flowed through the rock and contributed to brecciation (Figure 8c). Lateral entry points for water include bedding planes that intersect the present ground surface. Possible exit points for water are present where breccias extend to the ground surface. The subsurface water flow is towards the $\mathrm{N}$. 

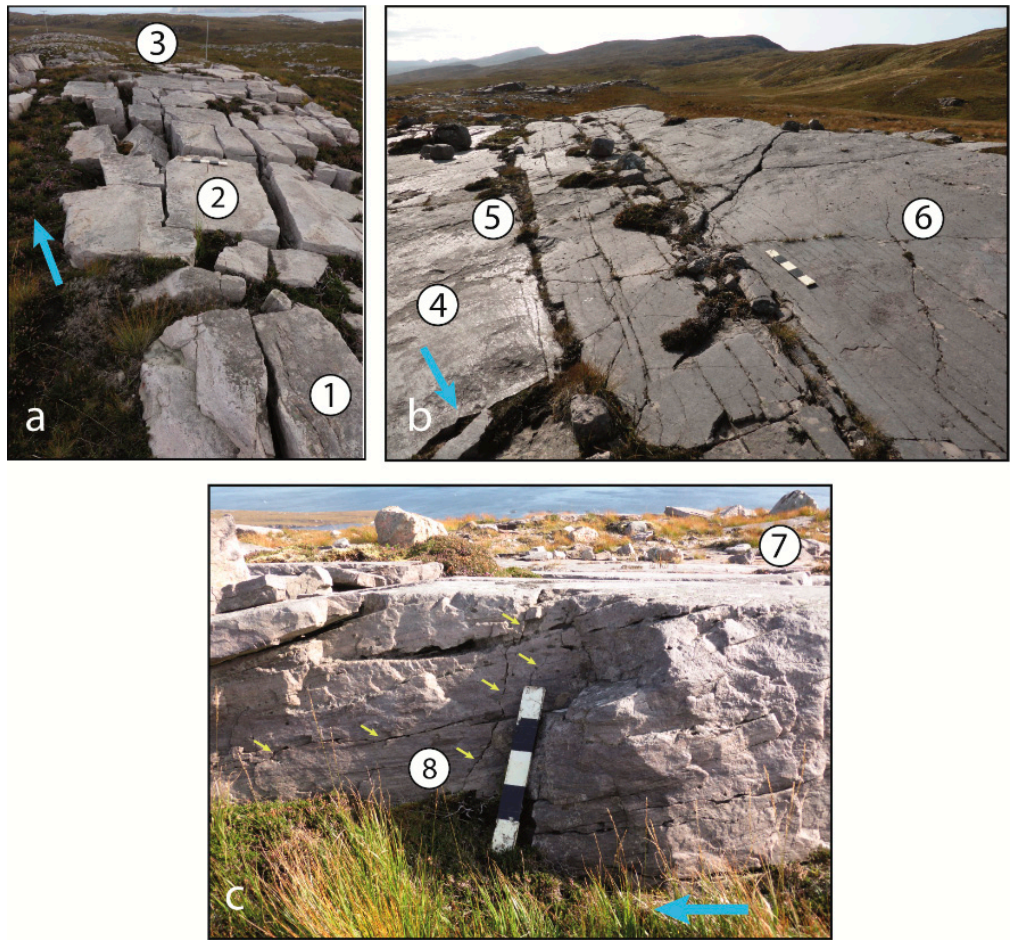

Figure 6. Fracture dilation and formation in quartz-arenite at Loch Eriboll. (a) Dilated joints and incipient bedrock disruption on a quartz-arenite pavement at NC 430638 . The fractures are preexisting and form an orthogonal pattern. (1) Abraded pavement surface. (2) Open vertical joints subparallel and transverse to ice flow. (3) Boulder spreads. (b) Open fractures on an abraded pavement above Loch Duail at NC 4305 6379. View along strike and up-ice. (4) Striated and polished abrasion surface. (5) Dilation of existing joints (J1). (6) Cracking of the uppermost bed of quartzarenite with formation of new fractures (J4). (c) Detail of the lateral edge of a quartz-arenite bed at NC 430638 with an abraded pavement (7) and showing in section the development of new fractures (arrowed) within and across the pre-existing fracture pattern (8: J4). The small cliff here lacks rounded and striated surfaces and so has lost blocks to late-stage glacial erosion.
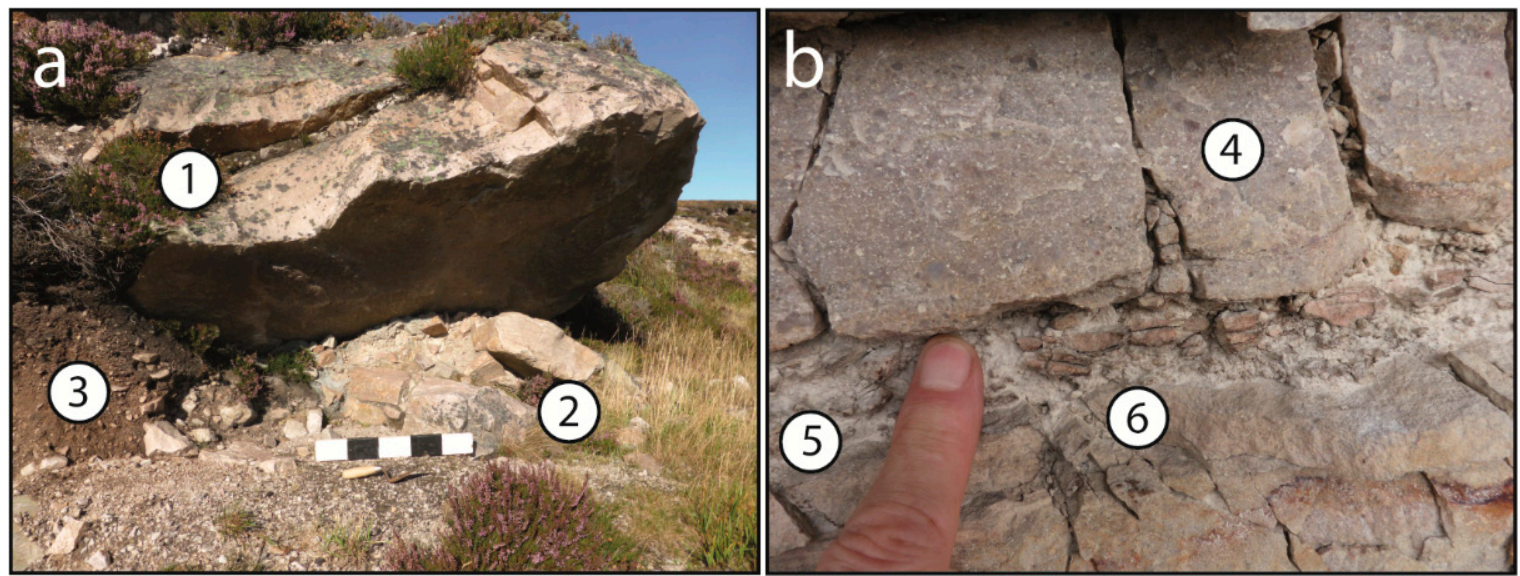

Figure 7. Open fractures and clastic sills. (a) Dilated fractures (J1) in a disrupted thick bed of quartz-arenite at NC 41845993. (1) Fracture fill (J5) of quartz-arenite gravel, including both angular and sub-rounded pebbles. (2) Fracture filled by rubble breccia and sand matrix. (3) Talus. (b) Dilated bed of silty sandstone and fracture fill at NC 4398 6213. (4) Crackle breccia (J2) with fragmentation along block edges. (5) Fill of laminated medium-grained sand. (6) Brecciated silty sandstone with detachment and rotation of rock fragments and admixture with sand. 

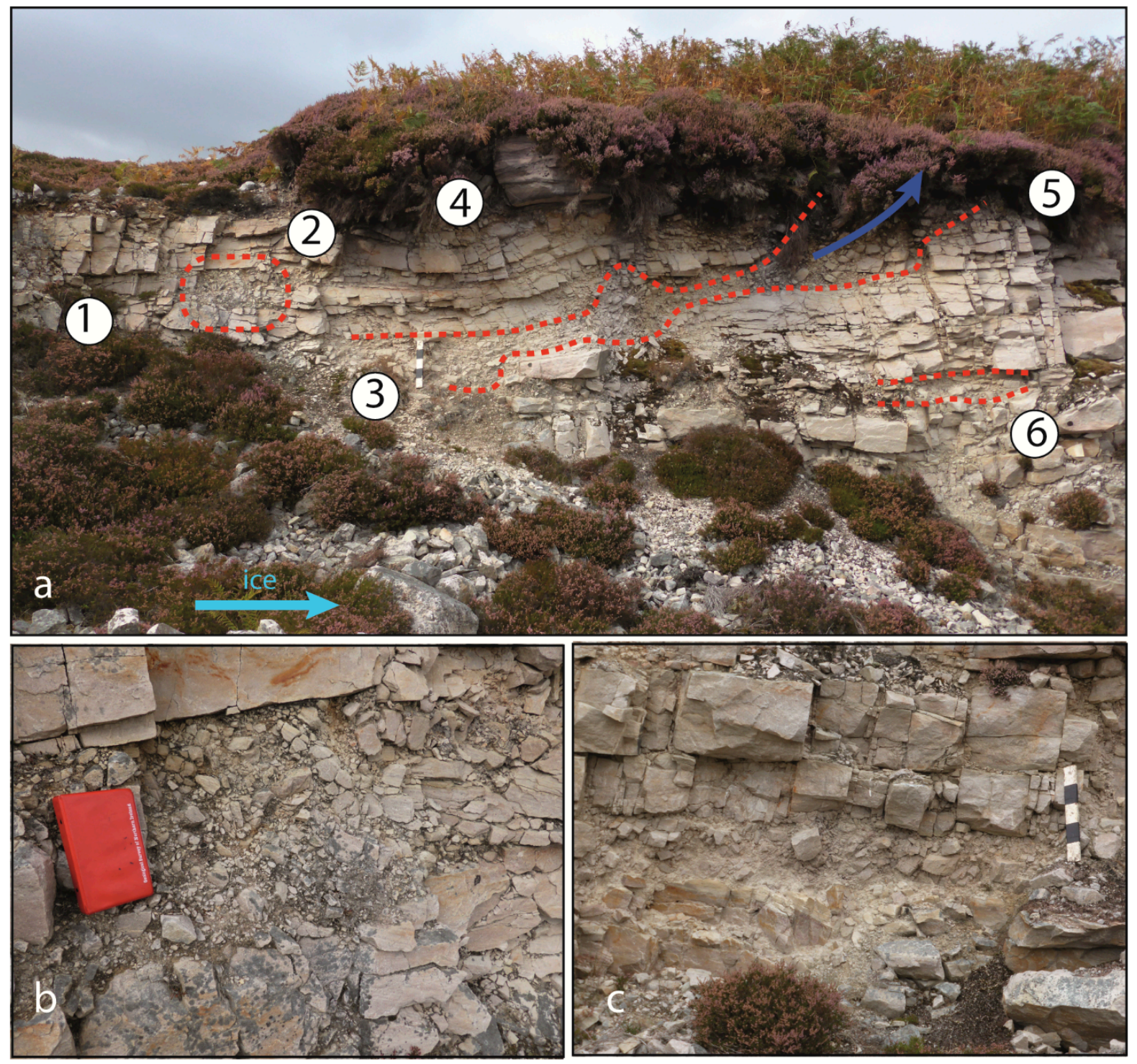

Figure 8. Groundwater overpressure: routing and brecciation. (a) Quarry at NC 43986213 . Scale bar is $50 \mathrm{~cm}$ long. (1) Crackle breccia (J2). (2) Pipe with mosaic and rubble breccia (J2), interpreted as a route for overpressure meltwater. (3) Brecciated quartz-arenite bed formed by dilation from overpressured meltwater and jacking of the near surface rock mass (J1). (4) Coherent quartz-arenite slab overlain by 20-40 cm thick till layer with subangular quartz-arenite clasts and a gneiss erratic boulder. (5) Site of possible venting of meltwater to the glacier bed. (6) A lower brecciated zone that continues to the N. (b) Detail of brecciated rock in pipe at (2). Notebook is $18 \mathrm{~cm}$ long. (c) Detail of lower brecciated zone $6 \mathrm{~m} \mathrm{~N}$ of (6) in Figure 8a.

The dilated and new fractures are unevenly distributed across rock pavements. Joint apertures together with the frequency of cracking increase towards the flanks and the lee sides of homoclinal ridges, while interior parts of pavements may show little or no damage (Figure $6 \mathrm{~b}$ ). On the western up-dip side of ridges, joint opening could not have been the product of mass movement, because it involved movement upslope. Instead, opening of joints along strike was associated with block removal from the ridge flank (Figures 5 and $7 \mathrm{~b}$ ). Joints on one pavement surface have apertures of up to $35 \mathrm{~cm}$ along strike compared to up to $18 \mathrm{~cm}$ along dip; apertures are greater along the line of former ice flow. Elsewhere, joint apertures appear to be uniform along the length of roches moutonnées (Figure 5). 


\subsection{Disruption of Rock Surfaces}

The opening of pre-existing fractures and the formation of new fractures represent disruption of the original rock mass of the quartz-arenite but with little bulk movement of the rock mass. Other features, however, indicate displacement of rock under subglacial traction. Tapering of joint apertures with depth suggest deformation of the uppermost quartz-arenite layers on the glacier bed. Individual blocks are seen to be moved slightly (Figures $6 \mathrm{a}$ and $7 \mathrm{a}$ ). This disruption is generally greatest on flank and lee faces, where small fracture caves may occur but also may extend across an entire rock sheet or large roche moutonnée (Figure 5).

Disruption from fracture opening and movement is seen on a small roche moutonnee (Figure 9a). The precursor surface of the hill retains polish, striae, and crescentic fractures (Figure $9 \mathrm{~b}$ ). Joint and bedding plane dilation extends to shallow (c. $1 \mathrm{~m}$ ) depths, and cracks occur across summit plates (Figure 9c). Additionally, the upper surface of the roche moutonnée has disintegrated to a depth of up $0.6 \mathrm{~m}$ (Figure 9b,d). The blocks released rest on the hillock surface or were transported for 1-10 $\mathrm{m}$ in a down-ice direction. The cumulative disruption is substantial.

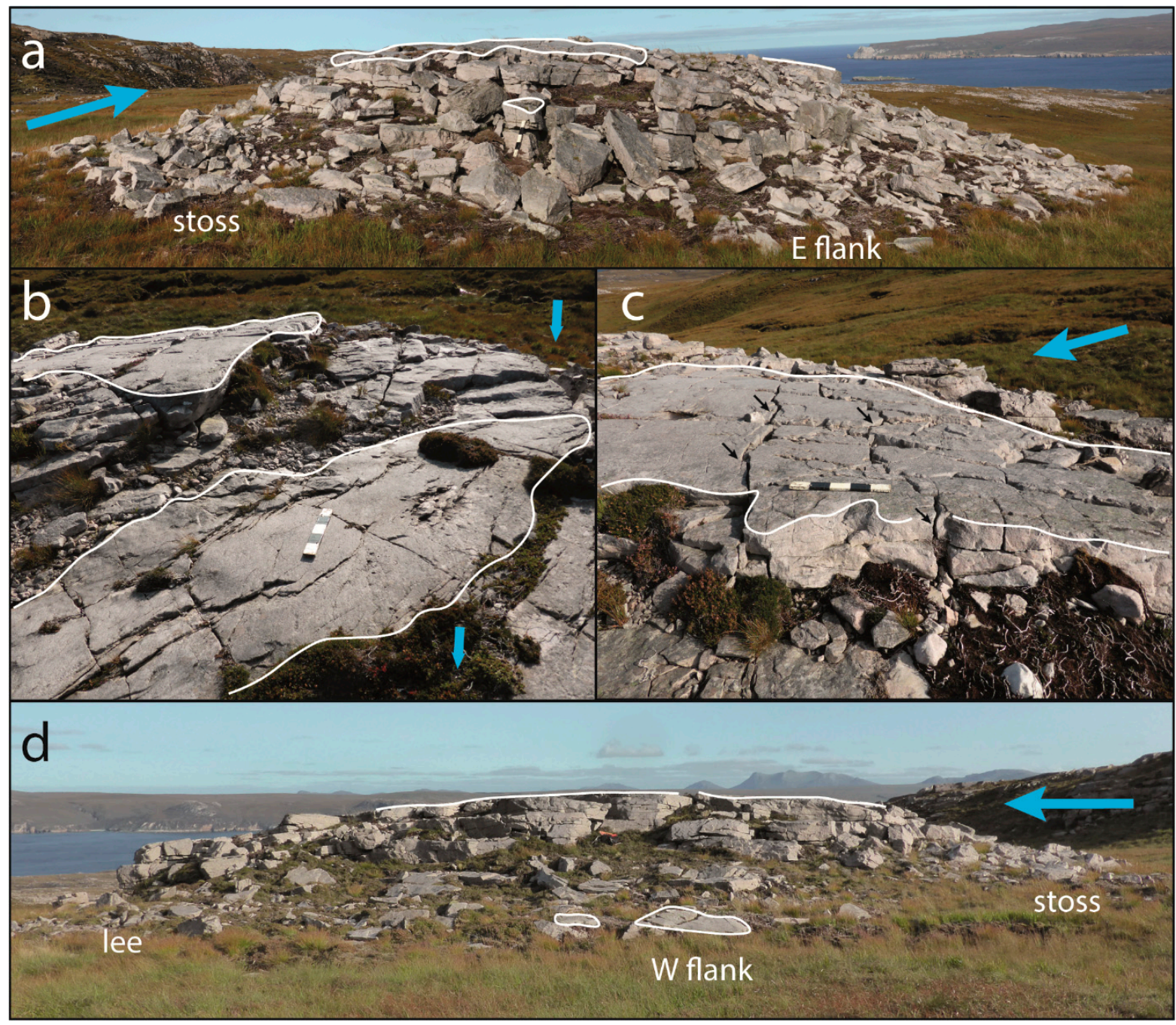

Figure 9. Disruption of a small roche moutonnée at NC 4312 6388. (a) Disintegration of quartz-arenite surfaces to $0.6 \mathrm{~m}$ depth on stoss and flank faces (D4). The scale bar is $50 \mathrm{~cm}$ long. (b) Intact polished and abraded upper surface (outlined in white) with intervening areas of slab loss (D6) with higher micro-roughness. (c) Abraded upper surface showing cracks (J4) developed after hydraulic jacking along the underlying bedding plane. (d) Northern flank of hill showing extensive block loss along the flank (D4) but limited plucking of the lee face. 


\subsection{Block Removal}

The most conspicuous damage to the precursor glacial forms at Loch Eriboll is where slabs and blocks are missing from abraded quartz-arenite pavements. The edges of the source sockets are sharp. The faces of the sockets lack glacial microforms. The bases of the sockets display the gently undulating form and $\mathrm{cm}$-scale micro-roughness typical of uneroded, newly exposed bedding planes (Figure 9b). Sockets also occur on stoss, flank, and lee faces of roches moutonnées. Sheets of rock $0.5-1.5 \mathrm{~m}$ thick were removed at sites at the base of lee-side cliffs on roches moutonnées and from rock steps on flat surfaces. Bedding planes provided décollement surfaces for detachment (Figure 10a).
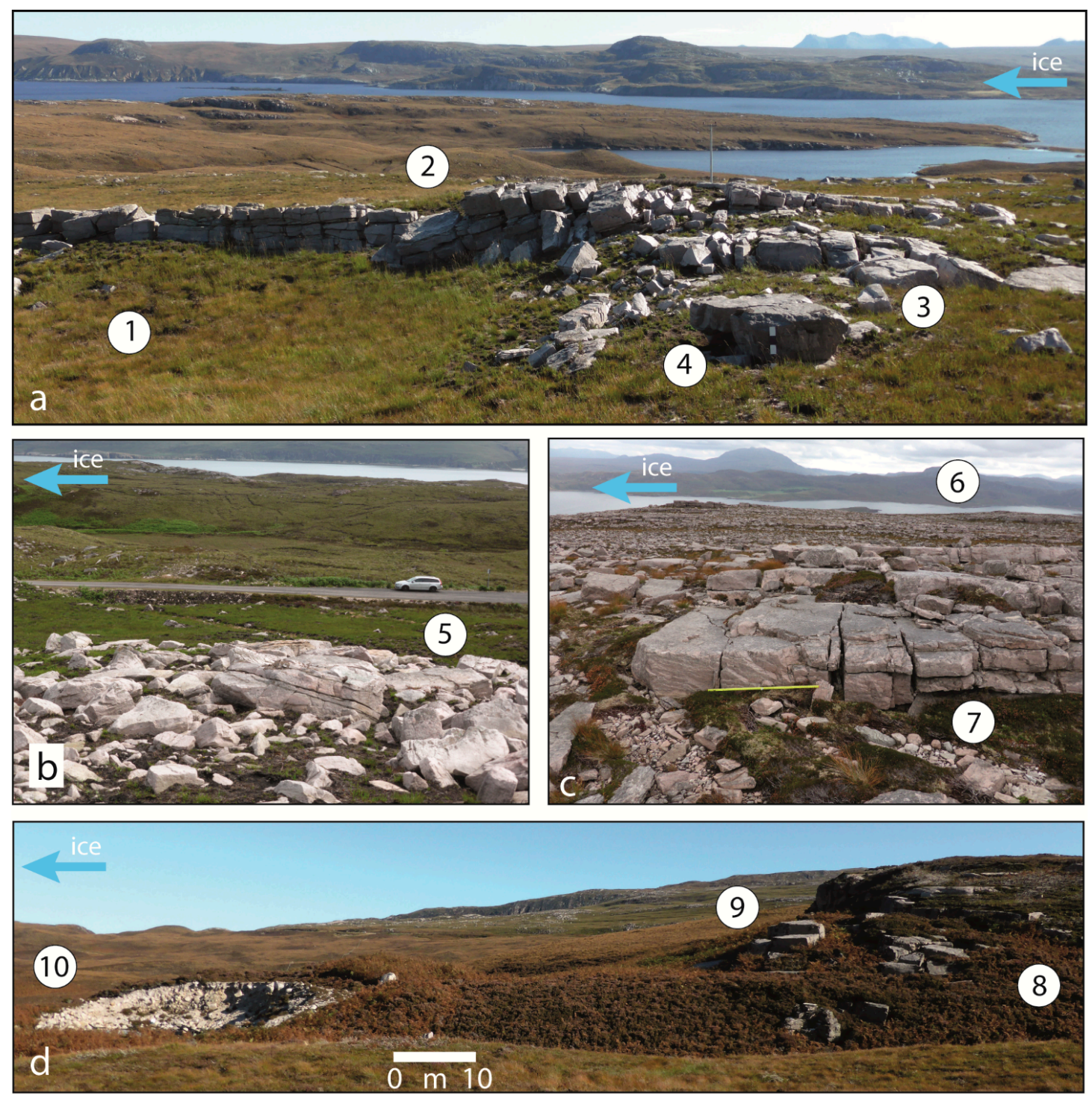

Figure 10. Glacial transport: tearaways, boulder spreads, and lee side plucking. (a) Ripped rock surface at NC 441637 with (1) basal décollement surface parallel to bedding (D3), (2) lateral cliff (D2) left after tearaway of rock sheet with block collapse, (3) dilation of vertical fractures (J1) and (4) transported boulder with $0.5 \mathrm{~m}$ scale bar. (b) Quartz-arenite boulder spread (T1) at NC 443 638. Note the abraded facets on several boulders (5). (c) Extensive quartz-arenite surface on Hill 314. Boulder spread (6) developed across thin quartz-arenite beds (T1). Thick bed of quartz-arenite with abraded top (7) with dilated joints (J1) and new fractures (J4). (d) Lee-side transport from a roche moutonnée (8) at NC 44516284 with removal of a small raft (9) (T3) from the lee face (D2) and formation of rubble till (10) exposed in a gravel pit (T6). Image mirrored to conform to SSW-NNE (right to left) ice flow direction seen in Figure 10a-c. 


\subsection{Block Transport}

Blocks removed from sockets cover a wide range of sizes. Thick beds of quartz-arenite provided sources for small rock rafts and mega-clasts (Figure 10d). Large numbers of boulders of b-axis $0.5-1.5 \mathrm{~m}$ size were shed from flank and lee cliff faces. The widespread disintegration of the surface layers of quartz-arenite beds of $<0.4 \mathrm{~m}$ thickness generated large volumes of angular quartz-arenite blocks of cobble to small boulder size.

Transport distances for quartz-arenite blocks onto basement surfaces were $<100 \mathrm{~m}$ (Figure 4e). On roches moutonnées, small rock rafts are found in down-ice positions 8-20 m away from lee-side cliffs, with short tails of bouldery rubble at slightly greater distances $(<50 \mathrm{~m})$ (Figure 6a). Quartz-arenite mega-clasts and small rafts were carried for $\sim 150 \mathrm{~m}$ from candidate source cliffs. Angular quartz-arenite boulders are found in down-ice positions (1-20 m) from source beds of similar thickness (Figures 7a, 9 and 11b). Where blocks can be traced to sources, glacial transport distances were short.

\subsection{Breccias, Boulder Spreads, Rubble Tills, and Moraines}

Breccias retain a discernible original rock mass structure. Bed thickness is an important control on block size, with boulder breccias generated from disintegration of thick beds and pebble to boulder breccias found where beds were $<0.4 \mathrm{~m}$ thick. Transitions between crackle, mosaic, and rubble breccias (Figure 11a-c) record progressive disruption and the onset of down-ice movement. Breccias are unevenly distributed, with some quartzarenite pavements remaining undisrupted whereas others show disruption from joint opening and the isolation and slight movement of blocks, forming mega-block and boulder breccias. Available sections indicate that thin beds of quartz-arenite are locally extensively brecciated. Brecciation is observed close to the flanks of meltwater channels, suggesting that overpressured water in subglacial channels permeated the adjacent bedrock. Brecciation is rarely observed below $2.5 \mathrm{~m}$, indicating that penetration of overpressured groundwater was restricted to shallow depths.

Spreads of quartz-arenite boulders cover areas of several ha (Figures $4 \mathrm{e}$ and 10b,c). The boulders overlie disrupted parts of roches moutonnées and rock pavements but also extend $\mathrm{N}$ of outcrops in the direction of former ice flow. Individual boulders may retain abraded facets, but edges remain sharp. Groups of boulders have b-axis lengths that are similar to in situ blocks of quartz-arenite beds at distances of 10-25 m from source outcrops. These boulder spreads are interpreted as products of subglacial disruption and short-distance transport.

Boulder-rich, locally clast-supported, massive, matrix-poor, and loose diamictons are widely exposed in road and quarry sections below $100 \mathrm{~m}$ a.s.l. These rubble tills have angular boulder- to pebble-sized clasts derived almost entirely from the Cambrian Basal Quartzite with rare boulders of gneiss, Pipe Rock, and Ordovician limestone. Vertical and lateral transitions are seen in this section from rubble breccias, which retain fitted blocks, to clast-supported, monomict rubble tills, where the original rock mass structure is destroyed (Figure 11d,e). Rubble tills seen in different exposures vary in clast size, clast edge rounding, and matrix content, the latter variously comprising rock chips, granules, and sand (Figure 11f,g). The changes in composition likely occurred during glacial transportas blocks were progressively more cracked and split, edges were broken, and comminution produced more matrix material. Where rubble tills can be traced to outcrop sources, transport distance were a few tens of metres. 

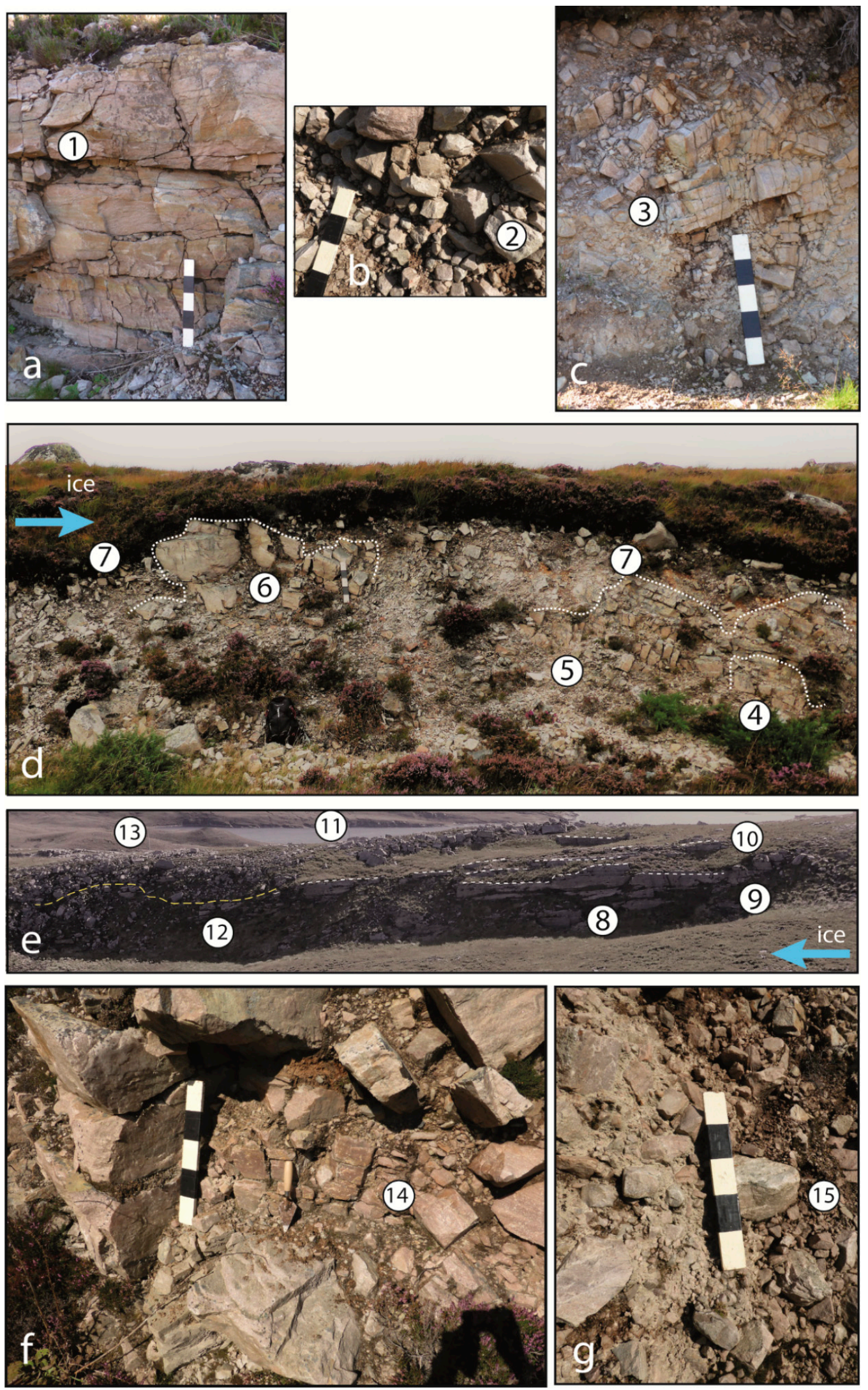

Figure 11. Transitions from breccia to rubble till. (a) Crackle breccia (J2) with sediment fill along horizontal fracture (1) at NC 425608. (b) Mosaic breccia (J2) without sediment infill at NC 395560. Rock mass structure still visible from fitting clasts (2). (c) Rubble breccia with displaced and rotated blocks (3) at NC 442625. (d) Roadside section at NC 443638 showing 
transitions between in situ rock (4), crackle and mosaic breccia (5), rubble breccia (6) and rubble till (7). The boundary between rubble breccia and rubble till is indicated by a dotted white line. The upper part of the rubble till (T6) has sparse gneiss erratics. (e) Relationships between rock, breccia, and rubble till. View of a cliff face along strike on the side of a small meltwater channel at NC 442639. The quartz-arenite remains undisrupted at shallow (c. $2.5 \mathrm{~m}$ ) depth in places (8) but disruption to mosaic and rubble breccias occurs nearby (9). Numerous décollement surfaces are seen (D3: dashed white lines) (10) where sheets of quartz-arenite were removed. Thick quartz-arenite beds are disrupted with formation of shallow boulder rubble breccia and surficial boulder spreads (11). Rubble till thickens on lee slopes, but the boundary between breccia and overlying rubble till is indistinct (dashed yellow line) (12). The ground surface carries a spread (T1) of small boulders (13). (f) Rubble till of angular boulders and cobbles with sandy matrix between clasts set within rubble breccia (14) at NC 4184 5983. (g) Monomict quartz-arenite rubble till with sandy matrix at NC 409581. Edge rounding on clasts after local transport (15).

Till is generally thinly developed or absent on slopes above $100 \mathrm{~m}$ a.s.l. above Loch Eriboll. Rubble till sheets 1-4 m thick occur on lower ground, resting on brecciated bedrock and undamaged quartz-arenite pavements. Rubble till also forms tails to outcrops and low ( $<5 \mathrm{~m}$ high) hummocks. Some accumulations of boulders and rubble till can be traced to sources at tearaway cliffs and to décollement surfaces (Figure 12a,b); the transport distance in one example is $\sim 80 \mathrm{~m}$ (Figure 12c,d). Large ( $>5 \mathrm{~m}$ high) moraine ridges formed of rubble till at Portnancon mark positions of the ice margin at $\sim 16.5 \mathrm{ka}$ [12]. Several meltwater channels found close to sea level have gravel fans at their exits composed of inclined beds of poorly sorted, angular to subrounded quartz-arenite cobble and boulder gravel; this material likely includes reworked breccia and rubble till.
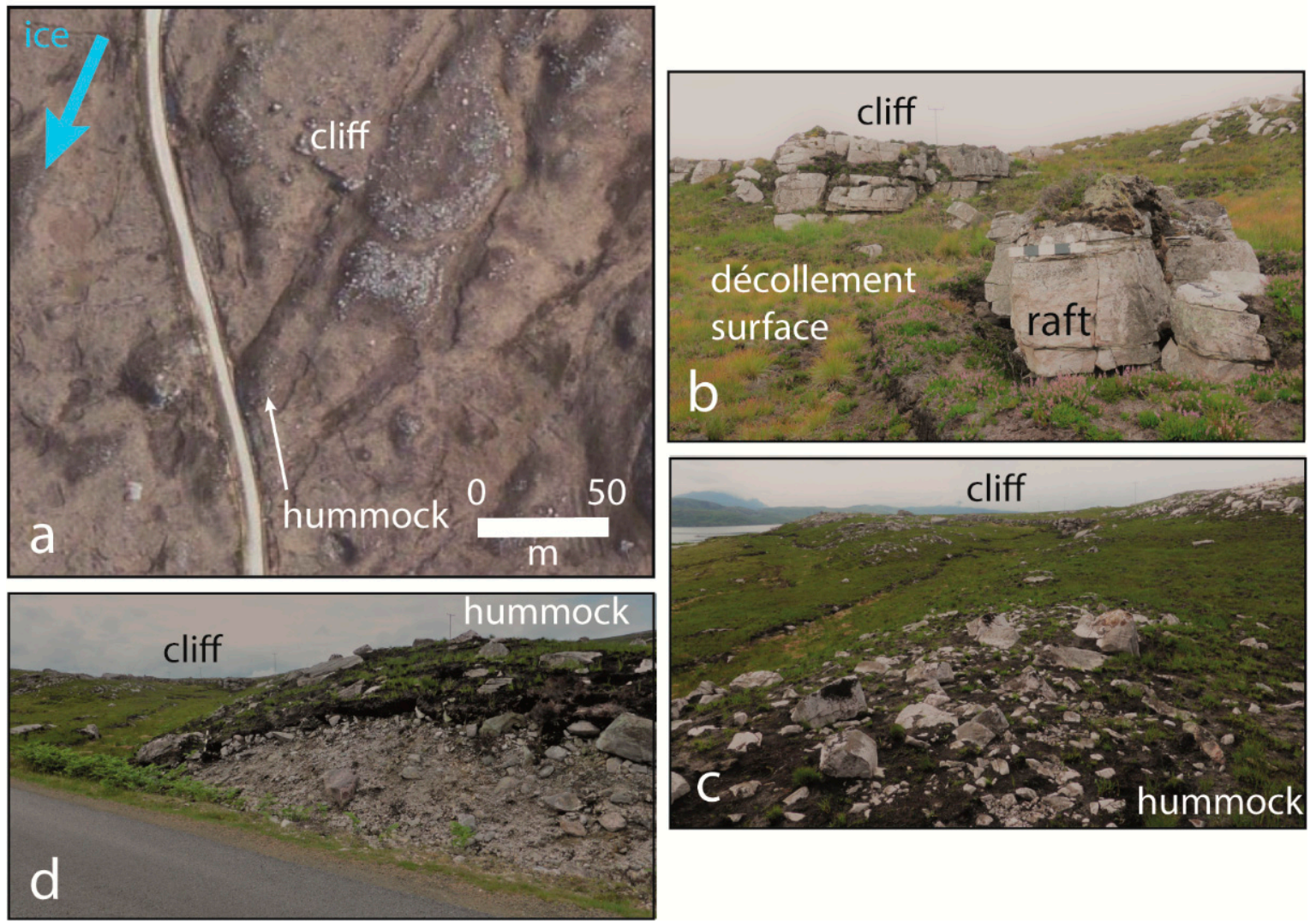

Figure 12. Ripping of rock sheets provides debris for rubble till hummocks. (a) Air photo showing the backing cliff and the area of rock sheet loss and the rubble till hummock. (b) Detail of the tearaway cliff (D2, D3, and T3). (c) Boulder-strewn surface of moraine hummock (T2). (d) Roadside section in rubble till composed entirely of quartz-arenite debris (T6). 


\subsection{Summary of Damage to Precursor Glacial Forms: Evidence for Glacial Ripping}

The pattern of damage to precursor glacial forms in quartz-arenite is summarized in Figure 13 and can be compared to the model of precursor glacial forms (Figure 4). Types of damage include many of the marker features for glacial ripping recognized in Sweden (Table 1). For the jacking criteria, markers J1-J2 and J4-J5 are well represented at Loch Eriboll, but the extent of J3, hydro-fracturing, is less certain due to the limited depths of exposures. For the disruption criteria, markers D1-D4 and D6 are well represented, but only a few small fracture caves are observed on lee faces. For the transport and the deposition criteria, markers T1-T4 and T6 are well represented, but mega-clast erratics are rare, likely a function of the relative dense fracture patterns in the bedrock. While individual marker features may develop through processes other than ripping, at Loch Eriboll different marker features occur together within a single area. Hence, the assemblage of features revealed in the field survey supports the hypothesis that groundwater overpressure and glacial ripping operated at Loch Eriboll during the last glaciation.

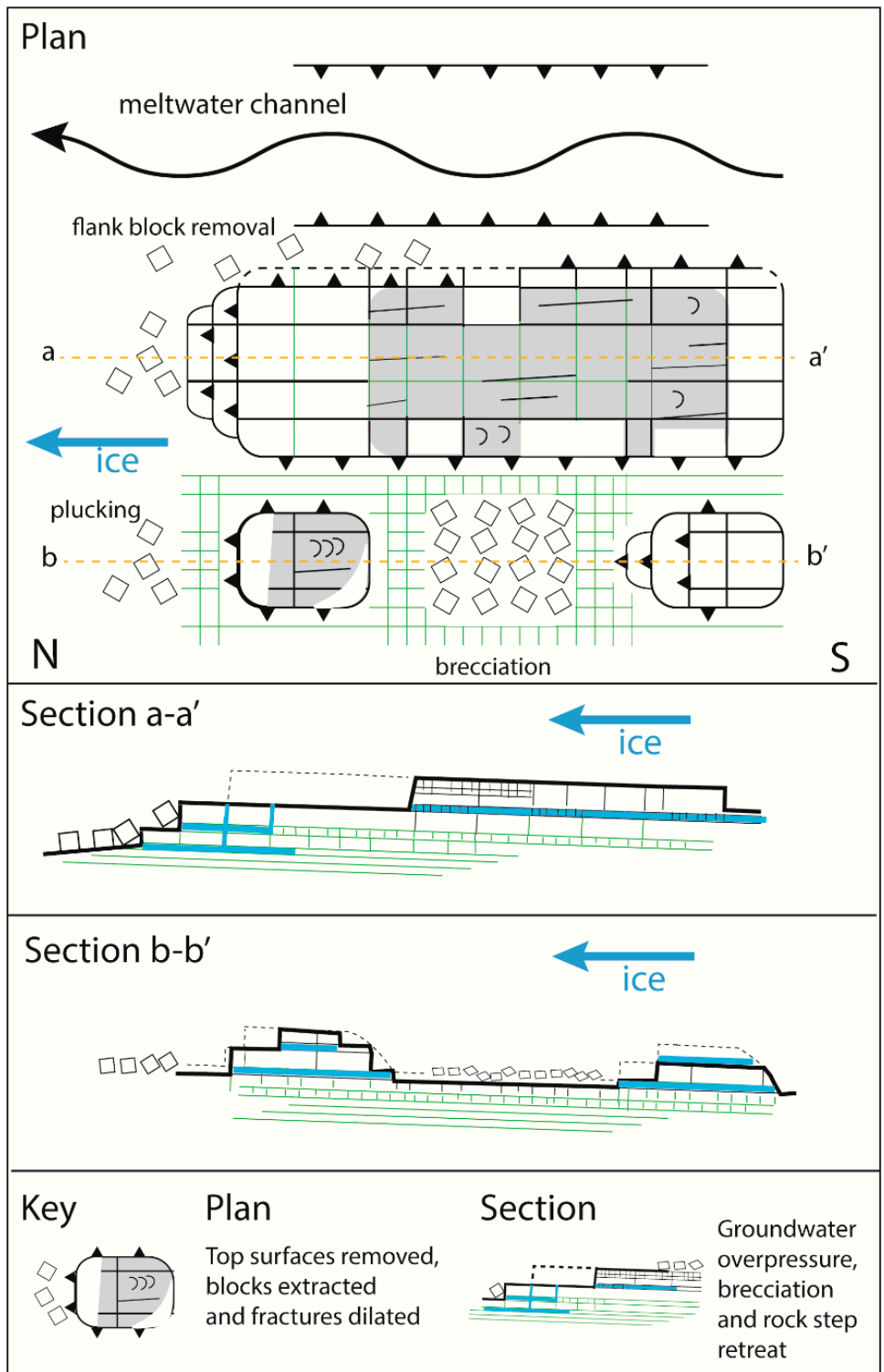

Figure 13. Model of the impacts of groundwater overpressure and glacial ripping on pre-existing glacial bedforms and surfaces in quartz-arenite at Loch Eriboll. Criteria from Table 1. Compare to Figure 4. 
In neighbouring gneiss terrain at Loch Eriboll, the precursor glacial features of whalebacks and roches moutonnées show no widespread damage. Damage is observed only on the northern flank of a meltwater channel at NC 442638, where abraded gneiss surfaces are jacked (J1), disrupted (D2, D4, D6), and displaced (T5), forming a short (20 m) boulder train which includes mega-clasts.

\section{Discussion}

\subsection{Hydraulic Jacking and Brecciation in Response to Subglacial Groundwater Overpressure}

Field observations at Loch Eriboll indicate that precursor glacial forms in quartzarenite were extensively damaged at a late stage in the last glaciation. The high fracture density of quartz-arenite [6] renders the rock susceptible to frost weathering [23], allowing the possibility that some damage relates to frost. However, intense frost weathering of Cambrian quartz-arenite is mainly confined to elevations above $400 \mathrm{~m}$ a.s.l. in the NW Highlands [23]. At elevations below $300 \mathrm{~m}$ a.s.l. at Loch Eriboll, many quartz-arenite pavements retain polished and striated surfaces, consistent with the excellent preservation of glacial striae on this lithology throughout the region [20]. The limited development of scree or loose blocks below lee-side rock steps indicates that modification of the quartzarenite landforms by periglacial frost weathering and post-glacial slope processes were minor at lower elevations [7]. Moreover, pavements with open and new vertical fractures and rock surfaces that locally disintegrated to form boulder spreads occur in proximity to undamaged pavements with closed fractures. Hence, the opening of existing joints and bedding planes and the development of new fractures were not primarily caused by Lateand post-glacial frost action.

Several features at Loch Eriboll indicate that fracture dilation and rock brecciation were a result of water entering subglacial fractures under overpressure. Open bedding planes in the shallow subsurface hold laminated sands deposited by water (Figure 7). Water flowing along bedding planes caused rotation, detachment, and movement of small rock fragments. Mosaic and rubble breccias also locally displayed fracture fills of sand transported by water into the rock as it became dilated. Water locally flowed along new hydro-fractures that transect the pre-existing structural fabric of the quartz-arenite (Figure 8). Fracture dilation extended over lengths of $100 \mathrm{~m}$ or more, causing disruption to depths of at least $0.5-2.5 \mathrm{~m}$ in some bedrock highs (Figure 5). The opening of sub-horizontal fractures, fracture fills of sediment, and disruption of roche moutonnées and rock sheets in parts of Sweden were attributed to subglacial hydraulic jacking of bedrock after overpressured groundwater entered fractures and lifted the overlying rock and ice sheet [1]. The open bedding planes and joints, the infill of open fractures by sediment, and the general disruption of nearsurface bedrock observed at Loch Eriboll are directly analogous features. We conclude that the entry of overpressured groundwater into the quartz-arenite via fractures led to hydraulic jacking at Loch Eriboll.

Vertical fracture apertures tend to increase towards the edges of the homoclinal ridges (Figure 6). Dilation of joints along strike forced blocks along edges to move slightly up-dip and upslope; joint opening in these settings could not have been caused by post-glacial down-slope mass movement. Dilation of the near-surface rock mass under groundwater overpressure, with vertical jacking and opening of bedding planes, was accompanied by lateral jacking along edges. Accommodation space for dilation and volumetric expansion of the near surface rock mass movement was likely provided by temporary separation of glacier ice from the bed by a layer of overpressured meltwater. Cases of glacier-soft bed decoupling and separation are well-documented [24], but glacier hard-bed separation is identified mainly within water-filled cavities in the lee of bedrock steps [25]. At Loch Eriboll, glacier hard-bed separation appears to be more extensive, resembling patterns of ice-bed separation documented during reorganization of distributed subglacial drainage systems [26].

Where the water which entered bedding planes was sediment-laden and deposited clastic sills, bedding planes were held open after groundwater pressure dropped. Where 
meltwater carried little sediment, dilated fractures, in theory, may have closed as water pressures fell. However, rock fragments broken from bedding plane surfaces during hydraulic jacking (Figure $7 \mathrm{~b}$ ) act as chockstones, which, combined with any slight movement in the near-surface rock, prevented jacked sheets of rock from resettling into original positions [27]. As groundwater overpressure dissipated and overburden load was reapplied from the glacier, new vertical fractures may have formed by flexing and cracking of brittle slabs (Figure 6b). The extensive cracks found on quartz-arenite pavements above open bedding planes at Loch Eriboll are likely products of this process, termed beam failure in Sweden [2].

The entry of overpressured water opened existing bedding planes and joints and formed new hydro-fractures. During an overpressure event, the effective pressure of the overlying ice is also reduced, which assists in the dilation of rock fractures at shallow depth. Water in fractures acted to lift and separate rock blocks, leading to widespread rock brecciation. Transitions between crackle, mosaic, and rubble breccia represent increasing disruption of the rock during fracture dilation. The opening of existing fractures, the formation of new fractures, and the associated brecciation represent an efficient but largely overlooked form of subglacial mechanical weathering. Groundwater overpressure was critical in preparing the quartz-arenite for erosion at Loch Eriboll.

\subsection{Movement and Transport}

Further disintegration of the near-surface rock mass and the entrainment of quartzarenite debris involved the application of tractive forces from the moving glacier. At Loch Eriboll, the main damage to precursor glacial forms was from the removal of blocks and sheets of rock. Socket distribution indicates that blocks were removed from tops and edges of homoclinal ridges on stoss, flank, and lee faces. Small rafts and mega-blocks were detached from lee faces. Exposed, unabraded bedding plane surfaces indicate the removal of rock sheets. Removal of the top surfaces of quartz-arenite pavement left décollement surfaces and low rock steps at tearaway sites (Figure 11e). Small roches moutonnées were severely disrupted (Figure 9), and others may have been destroyed. Several of these features have been identified as markers for glacial ripping on gneiss surfaces in Sweden (Figure 3 and Table 1).

The monomict composition, clast angularity and low sand matrix content of rubble tills indicate the incorporation of debris from rock blocks, rock sheets and breccias. Transport distances for these materials were short, mainly within 1-150 m of known sources. Rubble till forms the bulk of the glacigenic sediment present on the quartz-arenite at Loch Eriboll: little mature, polymictic till is observed in available sections.

\subsection{Importance of Structural Controls}

The bedding and fracture pattern of the Cambrian quartz-arenite exerted a strong control over the processes and the product of glacial ripping at Loch Eriboll. Long, continuous bedding planes were jacked open by overpressured groundwater, temporarily greatly increasing the hydraulic conductivity of the quartz-arenite at the glacier bed. Overpressured groundwater penetrated bedding planes along strike on homoclinal rock ridges and along dip towards the axis of these ridges. The high transmissivity of the (temporarily or permanently) dilated bedding planes allowed these layers to act as conduits for water movement, with volumetric expansion in the adjacent rock leading to its disruption and brecciation. Joint spacing and orientation, together with the variable thickness of subhorizontal beds, determined the size and the orthogonal shape of blocks within breccias and boulder spreads and the dimensions of source sockets. Microfractures in the quartz-arenite with similar orientations to the wider fracture network [9] likely strongly influenced patterns of further block cracking and fragmentation during glacial transport.

Fracture networks in Precambrian gneisses in east Sweden show, in general, shorter subhorizontal fractures, a greater range of fracture spacings, and less consistent fracture orientations [2]. Disruption in gneiss formed breccias but with block sizes that range up 
to mega-clasts and with more varied block shapes [2]. Consequently, boulder spreads and rubble tills in gneiss comprise much larger $(>1 \mathrm{~m})$ clasts than in quartz-arenites. This difference is evident at Loch Eriboll at one site where Lewisian gneiss was disrupted with development of a mega-clast boulder train. Generally, however, markers for glacial ripping are not developed on gneisses at Loch Eriboll. As subglacial meltwater fluxes and tractive forces were likely similar in neighbouring localities, the different incidence likely reflects the lower hydraulic transmissivity and the wider joint spacing of the Lewisian gneiss compared to bedded and jointed Eriboll sandstone.

\subsection{Timing of Glacial Ripping at Loch Eriboll}

The precursor glacial forms developed in quartz-arenite on the western flank of Loch Eriboll occurred after the LLGM at a time when ice flowed to the NNW. In contrast, directions of carry of quartz-arenite boulders, rafts, and rubble till, products of glacial ripping, indicate formation during ice flow to the NNE. Hence, the damage to the precursor forms occurred when ice flow became influenced by local topography during deglaciation. The lack of edge rounding on sockets, the short travel distances for rafts, boulders, and boulder spreads, the absence of overlying till cover on boulder spreads, and the accumulation of rubble till in terminal moraine ridges, such as at Portnancon [12], indicate that hydraulic jacking, disruption, and transport occurred shortly before final deglaciation.

The assemblage of features associated with glacial ripping at Loch Eriboll reported here occurs within a terrestrial ice margin for the BIIS dated by terrestrial cosmogenic nuclides to $17.6 \mathrm{ka}$. The margin at that time stood at $\sim 300 \mathrm{~m}$ a.s.l. on the ridge $\mathrm{W}$ of Loch Eriboll (Figure 2c). Projection of a reasonable ice surface profile from this lateral margin towards the axis of the glacial valley now occupied by Loch Eriboll suggests that rock surfaces now found close to present sea level were buried by a maximum thickness of $\sim 500 \mathrm{~m}$ of glacier ice, with thinning to $<100 \mathrm{~m}$ by $\sim 16.5 \mathrm{ka}$. While subject to $\sim 1 \mathrm{kyr}$ uncertainties, the ages suggest a duration of ice retreat across the Portnancon area of $\sim 1.1$ kyr. Debris generated by hydraulic jacking and disruption was transported as rubble and boulders over distances of $<100 \mathrm{~m}$ and often $<10 \mathrm{~m}$. Modelled basal ice velocities for the BIIS during deglaciation are $50-200 \mathrm{~m}^{-1}$ [28]. Hence, the ripping process set was likely completed within the estimated $1.1 \mathrm{kyr}$ interval that ice stood at the entrance of Loch Eriboll; the interval may have been shorter.

\subsection{Glaciological Conditions for Glacial Ripping at Loch Eriboll}

Glacial ripping occurred beneath thinning ice close to the retreating terrestrial margin of the Eriboll glacier. The glacial ripping process set represents the interplay between (i) hydraulic jacking and brecciation that reduced rock mass strength and disrupted the rock mass below the glacier bed and (ii) the tractive forces exerted by the glacier that drove brittle deformation, décollement, and block transport.

Gently-inclined bedding planes combined with relatively thin bedding $(<0.5-1 \mathrm{~m})$ predisposed the quartz-arenite to hydraulic jacking. High meltwater discharges reactivated an integrated system of rock-cut meltwater channels. Hydraulic jacking and brecciation adjacent to meltwater channels walls indicate that overpressure developed at times within the subglacial channels and that overpressured water penetrated the channel walls. Fracture opening and brecciation at other field locations show that overpressured water also penetrated towards the axes of roches moutonnées and homoclinal rock ridges (Figures 8a, 9 and 10). While overpressured water penetration was restricted to shallow $(0.5-3.0 \mathrm{~m})$ depth, the distribution of dilated fractures, brecciated quartz-arenite, and boulders spreads indicate that development of groundwater overpressure was extensive at the ice sheet bed.

Beneath thin ice close to a glacier margin, the normal compressive stress from ice loading is reduced. The glacier bed is in compression from the high basal shear stresses imposed by the steepness of ice surface slope [29]. At Loch Eriboll, the distribution of open joints and rock block and sheets removal indicates shallow brittle deformation in the 
quartz-arenite at sites where traction was applied from ice moving across the glacier bed. During episodes when groundwater overpressure developed at the glacier bed, normal (i.e., vertical) compressive stress was reduced to zero. This allowed traction to overcome resistance; the result was extensive glacial ripping and the production of rubble till.

The local scale variability in these processes is seen in the variability of patterns of damage to precursor glacial forms (Figure 14). The extensive abrasion surfaces on precursor glacial forms indicate that the BIIS was sliding over its rock bed but that resistance to rock movement exceeded ice traction forces across rock surfaces, except on lee faces. Where no damage is seen on rock surfaces (Type A), the dominance of resisting forces persisted until final glacier retreat. As neighbouring surfaces were subject to similar tractive forces, the lack of damage suggests that groundwater overpressure did not develop at these locations. In contrast, damage of Types B-D indicates the former action of overpressured groundwater. Type B damage with brecciation but with no or metre-scale transport distances indicates the build-up of groundwater overpressure and rock dilation but without tractive forces sufficient to strip away the weakened rock and rubble. In other settings, this lack of erosion might be attributed to a cover of cold-based ice, a frozen substrate, or to a protective cover of till [30]. At Loch Eriboll, however, these explanations do not apply because (i) the evidence for former water flow through rock fractures at shallow depth indicates a thawed bed and (ii) the quartz-arenite pavements lack till cover. Rather, it is likely that tractive forces remained too low to overcome resistance due to the persistence of the smooth pavement surfaces, despite cracking and joint opening (Figures 6 and 7). Type C damage indicates that tractive forces overcame resistance to remove blocks, but only on lee slopes. This damage represents a form of plucking where resisting forces on the lee slopes may be reduced by the presence of a lee-side cavity and by the build-up of groundwater overpressure around the cavity [7]. Type D damage involves socket formation and block loss on stoss, flank, and lee faces. Patterns of joint dilation and cracking indicate water penetration at overpressure from the edges of bedrock highs and application of tractive forces sufficient to extract blocks from these locations. Type E damage records the removal of entire rock sheets from bedrock highs and pavements. In this case, fracture dilation and brecciation were accompanied by tractive forces sufficient to move slightly or to remove entirely the uppermost rock layer(s).

The damage to precursor glacial forms represents a switch in the subglacial erosion regime from dominant abrasion to dominant glacial ripping caused by a fundamental change in the balance of resisting and tractive forces at the glacier bed. Under an abrasion regime, resisting forces dominate, except on lee-side cliffs, where blocks may be removed into subglacial cavities by plucking [31]. Rock surfaces remain in situ and are worn down slowly as debris in the sole of the glacier crosses rock surfaces under ice load [32]. Under a glacial ripping regime, blocks and sheets of rock are entrained in stoss, flank, and lee positions, and entire roches moutonnées and rock sheets may partly or wholly disintegrate. Under glacial ripping, subglacial tractive forces were sufficient to overcome resistance to movement across large parts of the bedrock surface. Tractive forces were likely similar across and between individual quartz-arenite pavements with and without damage; the critical control on the pattern of glacial ripping at Loch Eriboll was the distribution of groundwater at overpressure.

\subsection{Erosional Impact of Glacial Ripping}

Glacial erosion mainly involves processes of abrasion, plucking, meltwater erosion, and glacial ripping. Precursor glacial forms in quartz-arenite lack evidence for the operation of ripping but carry extensive abraded surfaces and plucked lee surfaces and include rockcut meltwater channels. Glacial abrasion of the Cambrian quartz-arenite is likely slow, as the rock is very hard $[6,11]$. At Loch Eriboll, quartz-arenite pavements carry only a few erratic boulders, and till cover is absent from wide areas (Figures 6 and 7); production of rock debris was limited during the time of formation of the precursor glacial forms, limiting the tools for abrasion. Circumstantial evidence suggests that the precursor glacial 
forms were mainly shaped by slow abrasion accompanied by lee-side and lateral plucking over a period that potentially spanned the $\sim 20 \mathrm{ka}$ of the last glaciation. The damage to the precursor glacial forms through glacial ripping was, in contrast, likely completed in $<1100 \mathrm{y}$. The ripping process set was highly effective in the erosion of rock surfaces, removing rock to depths of $0.5-3.0 \mathrm{~m}$ where it operated. Erosion rates from glacial ripping were likely high compared to abrasion.

\begin{tabular}{|c|c|c|c|c|c|c|}
\hline $\begin{array}{l}\text { Type of } \\
\text { damage }\end{array}$ & Distribution & & Effects & $\begin{array}{l}\text { Marker } \\
\text { features }\end{array}$ & $\begin{array}{l}\text { Groundwater } \\
\text { pressure }\end{array}$ & $\begin{array}{l}\text { Balance of resisting (R) } \\
\text { and traction }(T) \text { forces }\end{array}$ \\
\hline & & $\stackrel{\longleftarrow}{\longleftarrow}$ & $\begin{array}{l}\text { Precursor glacial form persists. } \\
\text { Before deglaciation, abrasion } \\
\text { operated across entire surface. }\end{array}$ & None & Low & $\mathrm{R}>\mathrm{T}$ \\
\hline $\mathrm{E}$ & & & $\begin{array}{l}\text { Extensive brecciation but } \\
\text { with no or little } \\
\text { block movement }\end{array}$ & $\begin{array}{l}\text { J1-J5, } \\
\text { T1 }\end{array}$ & $\begin{array}{l}\text { High across } \\
\text { entire rock surface }\end{array}$ & $\mathrm{R}>\mathrm{T}$ \\
\hline & & & Lee side block loss & $\begin{array}{l}\text { D2, D5, } \\
\text { T3-T6 }\end{array}$ & High on lee face & $\mathrm{R}>\mathrm{T}$ except on lee face \\
\hline & & & $\begin{array}{l}\text { Lee, flank and stoss side } \\
\text { block loss }\end{array}$ & $\begin{array}{l}\text { J1-J5 } \\
\text { D2-D6 } \\
\text { T1, T3- } \\
\text { T6 }\end{array}$ & High on all edges & $\begin{array}{l}\mathrm{R}<\mathrm{T} \text { except across } \\
\text { core of hill }\end{array}$ \\
\hline$E$ & & & Rock sheet loss & $\begin{array}{l}\text { J1-J5 } \\
\text { D1-D6 } \\
\text { T1-T6 }\end{array}$ & $\begin{array}{l}\text { High across } \\
\text { entire rock surface }\end{array}$ & $\mathrm{R}<\mathrm{T}$ \\
\hline
\end{tabular}

Figure 14. Summary of types of damage in quartz-arenite at Loch Eriboll and inferred links to subglacial groundwater pressure and tractive forces. Abraded surfaces are shaded; surfaces damaged late in the last glaciation are unshaded.

The extensive brecciation induced by groundwater overpressure at Loch Eriboll represents subglacial mechanical weathering of the bedrock mass. The rock mass strength was significantly reduced at shallow depth. The debris seen today in partly disintegrated roches moutonnées, rock breccia, and rubble till would be easily entrained and evacuated by renewed ice advance. Collectively, these sources represent large volumes of debris. Glacial ripping was not only a highly effective process of erosion in the quartz-arenite at Loch Eriboll; ripping also operated as an efficient till factory and prepared the quartz-arenite for future glacial erosion.

\subsection{Glacial Ripping and Rubble Till Formation in Other Sedimentary Rocks}

Studies of glacial erosion of hard sedimentary rocks are few, despite the large extent of these terrains [33]. Application of the checklist of candidate features for glacial ripping to several published studies from these sedimentary terrains (Table 2) suggests that many marker features for glacial ripping are present at other locations that were formerly covered by Late Pleistocene ice sheets in the Northern Hemisphere (Table 2). Moreover, examples of transitions from rock breccia to rubble till and to more mature, matrix-supported diamictons, as observed at Loch Eriboll (Figure 11), were described for hard sandstones and limestones (and, in some cases, their metamorphosed equivalents) elsewhere beneath the BIIS in Scotland [16,34], northern England [35], Wales [36], and western Ireland [15]. Most of these examples are from areas such as Loch Eriboll, where till cover is thin or absent. 
In sedimentary terrains where thick tills were deposited beneath the last BIIS, such as the Midland Valley of Scotland, the coastal zone of north-east England, and central Ireland, there appear to be few records of basal rubble tills at the surface. Hence, it is likely that, in common with other subglacial erosion mechanisms [30], glacial ripping and rubble till formation are suppressed beneath thick till cover.

Table 2. Other potential locations for glacial ripping in hard sedimentary rocks from published literature.

\begin{tabular}{|c|c|c|c|c|}
\hline Ice Sheet & Location & Rock Types & Criteria & Reference(s) \\
\hline \multirow[t]{10}{*}{ BIIS } & Loch Eriboll, Scotland & Cambrian quartz-arenite & $\mathrm{J} 1, \mathrm{~J} 2, \mathrm{~J} 4, \mathrm{~J} 5, \mathrm{D} 1-\mathrm{D} 4, \mathrm{D} 6, \mathrm{~T} 1-\mathrm{T} 4, \mathrm{~T} 6$ & This paper \\
\hline & Loch Quoich, Scotland & Moine psammite (meta-sandstone) & $\mathrm{J} 1-\mathrm{J} 3, \mathrm{~J} 5, \mathrm{~T} 6$ & {$[37]$} \\
\hline & Meads of St John, Scotland & Devonian sandstone & $\mathrm{J} 1-\mathrm{J} 3, \mathrm{~J} 5, \mathrm{~T} 3$ & {$[38]$} \\
\hline & North Corbelly, Dumfries, Scotland & $\begin{array}{l}\text { Weakly-metamorphosed } \\
\text { Palaeozoic sandstones, mudstones }\end{array}$ & $\mathrm{J} 2, \mathrm{~J} 3, \mathrm{~T} 6$ & [39] \\
\hline & Fanore, County Clare, Ireland & Carboniferous limestone & $\mathrm{J} 1-\mathrm{J} 3, \mathrm{~J} 4$ ?,J5, D2, D3, T1, T3, T5, T6 & {$[40]$} \\
\hline & Clogher Bay, Dingle Peninsula, Ireland & $\begin{array}{l}\text { Palaeozoic sandstone, } \\
\text { limestone, mudstone }\end{array}$ & $\mathrm{J} 1-\mathrm{J} 3, \mathrm{~J} 5, \mathrm{~T} 3, \mathrm{~T} 5, \mathrm{~T} 6$ & {$[41]$} \\
\hline & Killala Bay, Mayo, Ireland & Carboniferous limestone & J2, D3, D4, T3, T5, T6 & [42] \\
\hline & Anglesey, Wales & $\begin{array}{c}\text { Cambrian } \\
\text { meta-sandstones and mudstones }\end{array}$ & J1-J3, J5, D3, T3, T5, T6 & {$[43]$} \\
\hline & Teesdale, England & $\begin{array}{l}\text { Carboniferous } \\
\text { sandstone, limestone }\end{array}$ & J1-J2, D1, D3, T3, T6 & [35] \\
\hline & Whitburn Bay, Durham. England & Permian limestone & $\mathrm{J} 1-\mathrm{J} 3, \mathrm{~J} 5, \mathrm{~T} 6$ & {$[44]$} \\
\hline FIS & Częstochowa, Poland & $\begin{array}{l}\text { Cretaceous marl, } \\
\text { Jurassic limestone }\end{array}$ & $\mathrm{J} 2, \mathrm{D} 3, \mathrm{~T} 3, \mathrm{~T} 6$ & [45] \\
\hline \multirow[t]{3}{*}{ LIS } & Dummer moraine, Ontario, Canada & Ordovician limestone & $\mathrm{J} 1-\mathrm{J} 3, \mathrm{~J} 4$ ?, D1-D3, T1-T6 & [46] \\
\hline & Montréal city, Canada & & $\mathrm{J} 1, \mathrm{~J} 2, \mathrm{~J} 4$ ?, D2, D3. D5, T3 & {$[47,48]$} \\
\hline & Muskeg River, Alberta, Canada & Cretaceous sandstone & $\mathrm{J} 1-\mathrm{J} 3, \mathrm{~J} 5, \mathrm{~T} 6$ & [49] \\
\hline CoIS & Cranbrook, British Columbia & Proterozoic quartzite & $\mathrm{J} 1-\mathrm{J} 3, \mathrm{~J} 5, \mathrm{D} 3, \mathrm{~T} 3, \mathrm{~T} 6$ & {$[50]$} \\
\hline
\end{tabular}

BIIS British Irish Ice Sheet; FIS Fennoscandian Ice Sheet; LIS Laurentide Ice Sheet; CoIS Cordilleran Ice Sheet.

Where brecciation of rock, detachment of rock rafts, and generation of rubble till in hard sedimentary rocks are reported, these features are commonly attributed to glacitectonics. Aber et al. [51] defined glaciotectonism as 'glacially induced structural deformation of bedrock and/or drift masses as a direct result of glacier ice movement and loading'. The quartz-arenite at Loch Eriboll and the other rock masses listed in Table 2 clearly were disrupted and moved by forces generated beneath moving glaciers and thus are glacitectonic in origin. Quartz-arenite rubble breccia also might be described as a 'glacitectonite' [52]. 'Glacitectonics', however, is a broad, generic term that can be applied to a wide range of features of subglacial erosion, transport, and deposition linked to ice dynamics, substrate rheology, and ice-bed coupling [53]. While 'glacial ripping' can be regarded as a subset of glacitectonics, jacking, disruption, and transport are specific components of the newly recognised process sequence, each of which is linked to a distinctive sub-set of marker features (Figure 3). Moreover, 'glacitectonics' is often associated with the movement of intact rock and sediment as rafts [54], whereas 'glacial ripping' is a distinctive process of glacial erosion that progresses quickly to the complete disintegration of a rock mass and the production of rubble till.

At Loch Eriboll, in eastern Sweden and at sites such as those in Table 2, the tractive forces generated by glacitectonics acting on neighbouring bedrock surfaces in each area were likely similar, but the features associated with glacial ripping or shallow glacitectonics were not evenly distributed between these surfaces. At Loch Eriboll, quartz-arenite pavements damaged by jacking and disruption occur at similar elevations and within a few hundred metres of undamaged pavements developed on quartz-arenite beds of similar thickness. Gneiss surfaces at Loch Eriboll at similar elevations to quartz-arenite surfaces generally lack ripping features. In Uppland, Sweden, boulder spreads formed after jacking, disruption, and local transport of gneiss blocks occur in corridors and patches between ice-flow parallel belts that lack boulder spreads and display abraded bedrock hills with plucked lee-side faces [13]. Specifically, areas of the glacier bed that do not show 
boulder spreads also do not show widespread evidence of hydraulic jacking and fracture dilation. The distribution of markers for subglacial jacking makes clear that pressurized groundwater exerts a fundamental control on the pattern of operation of the ripping process sequence.

The capacity of glaciers to detach and transport large blocks of soft sediment and weak sedimentary rock is widely recognised. Pressurised meltwater plays a key role by minimising friction along low angle bedding planes $[55,56]$ and in subglacial shearing and thrusting in sub-marginal settings [57]. Deformation associated with transport is focused along thin, water-lubricated zones, often allowing thrust blocks of non- or weakly lithified and unfrozen sediment to move with only limited internal deformation $[29,54]$. Thrust stacks record repeated events of thrusting, hydrofracturing, and water-escape [58]. The initial detachment of soft sediment blocks in ice marginal zones took place in response to ice-push and gravity-spreading at the margins of retreating glaciers in Iceland [56], Denmark [58], and Sweden [59]. Beneath the retreating ice margin at Loch Eriboll, glaciological conditions were broadly similar, with high meltwater fluxes, episodically high groundwater pressure, and thin ice cover. The different substrate provided by hard, fractured quartz-arenites, however, led to a dominance of brittle deformation and to disintegration of unfrozen rock sheets into rubble over short transport distances.

While evidence for glacial ripping at Loch Eriboll and in other hard sedimentary rocks is often of restricted extent, likely due to limited rock exposure, glacial ripping operated more widely. Glacitectonic structures are reported in sedimentary rocks in and around the Baltic Sea $[60,61]$ and the Great Lakes of North America [62]. Markers for glacial ripping are widely present, implying a potentially significant role for this process in the erosion and the overdeepening of these and other marine and freshwater basins. Brecciation of the Cambrian quartz-arenite at Loch Eriboll generated large volumes of rock rubble that were reworked into rubble tills. Much larger till factories operated beneath the last BIIS in western Ireland [40] and the last LIS in southern Ontario [63,64], Canada, where thick beds of limestone were likely jacked under groundwater overpressure and disrupted, cracked, and crushed to form mega-breccias and mega-rubble tills. While the contribution of glacial ripping to the glacial erosion budgets beneath former Northern Hemisphere ice sheets remains to be generally quantified, its impact may equal or exceed the combined impact of other glacial erosion processes on hard sedimentary rock beds.

\section{Conclusions}

Application of a checklist of marker features for the operation of glacial ripping in Precambrian gneisses in Sweden reveals that many analogous features are present on Cambrian quartz-arenite in NW Scotland. Hydraulic jacking was driven by the entry of overpressured water along bedding planes and thin quartz-arenite beds and lifted the rock surface and the overlying glacier ice, causing fracture dilation, cracking, and brecciation. Further disruption of the quartz-arenite occurred as traction was applied to the disrupted rock mass at the glacier bed, causing brittle deformation, décollement, and rock block removal. The impact of glacial ripping was variable and controlled largely by the distribution of overpressured groundwater across the former glacier bed. Glacial ripping at Loch Eriboll operated intensively during the last $\sim 1.1 \mathrm{kyr}$ of the last glaciation in a submarginal, terrestrial setting with high discharges of meltwater. The production of large volumes of breccia and rubble till indicates that glacial ripping was an important process for mechanical weathering, glacial erosion, and till production. A literature survey indicates that potential markers for glacial ripping occur in hard sedimentary rocks in many other formerly glaciated areas.

Author Contributions: Conceptualization, A.M.H.; methodology, A.M.H., M.K.; validation, A.M.H., H.M. and M.K.; formal analysis, A.M.H., H.M. and M.K.; writing-original draft preparation, A.M.H.; writing-review and editing, A.M.H., H.M. and M.K.; visualization, A.M.H., H.M. and M.K. All authors have read and agreed to the published version of the manuscript. 
Funding: This research received no external funding.

Institutional Review Board Statement: Not applicable.

Informed Consent Statement: Not applicable.

Data Availability Statement: Data is contained within the article.

Acknowledgments: We thank the anonymous referees for their constructive commentary.

Conflicts of Interest: The authors declare no conflict of interest.

\section{References}

1. Hall, A.M.; Krabbendam, M.; van Boeckel, M.; Goodfellow, B.W.; Hättestrand, C.; Heyman, J.; Palamakumbura, R.N.; Stroeven, A.P.; Näslund, J.-O. Glacial ripping: Geomorphological evidence from Sweden for a new process of glacial erosion. Geogr. Ann. Ser. A Phys. Geogr. 2020, 102, 333-353. [CrossRef]

2. Krabbendam, M.; Arnhardt, C.; Palamakumbura, R.; Hall, A.M. Rock fracturing by subglacial hydraulic jacking in basement rocks, eastern Sweden: The role of beam failure. GFF 2021. accepteded.

3. Park, R.G.; Stewart, A.D.; Wright, D.T. The Hebridean terrane. In The Geology of Scotland; Trewin, N.H., Ed.; The Geological Society London: London, UK, 2002; pp. 45-61.

4. Swett, K.; Klein, G.D.; Smit, D.E. A Cambrian tidal sand body: The Eriboll Sandstone of Northwest Scotland: An ancient-recent analog. J. Geol. 1971, 79, 400-415. [CrossRef]

5. Laubach, S.; Diaz-Tushman, K. Laurentian palaeostress trajectories and ephemeral fracture permeability, Cambrian Eriboll Formation sandstones west of the Moine Thrust Zone, NW Scotland. J. Geol. Soc. 2009, 166, 349-362. [CrossRef]

6. McKie, T. Barrier island to tidal shelf transition in the early Cambrian Eriboll Sandstone. Scott. J. Geol. 1989, 25, 273-293. [CrossRef]

7. Krabbendam, M.; Glasser, N.F. Glacial erosion and bedrock properties in NW Scotland: Abrasion and plucking, hardness and joint spacing. Geomorphology 2011, 130, 374-383. [CrossRef]

8. Krabbendam, M.; Bradwell, T. Lateral plucking as a mechanism for elongate erosional glacial bedforms: Explaining megagrooves in Britain and Canada. Earth Surf. Process. Landf. 2011, 36, 1335-1349. [CrossRef]

9. Hooker, J.; Laubach, S.; Gomez, L.; Marrett, R.; Eichhubl, P.; Diaz-Tushman, K.; Pinzon, E. Fracture size, frequency, and strain in the Cambrian Eriboll Formation sandstones, NW Scotland. Scott. J. Geol. 2011, 47, 45-56. [CrossRef]

10. Bradwell, T.; Stoker, M.S.; Larter, R. Geomorphological signature and flow dynamics of The Minch palaeo-ice stream, northwest Scotland. J. Quat. Sci. 2007, 22, 609-617. [CrossRef]

11. Everest, J.; Bradwell, T.; Stoker, M.; Dewey, S. New age constraints for the maximum extent of the last British-Irish Ice Sheet (NW sector). J. Quat. Sci. 2013, 28, 2-7. [CrossRef]

12. Mathers, H. The Impact of the Minch Palaeo-Ice Stream in NW Scotland: Constraining Glacial Erosion and Landscape Evolution through Geomorphology and Cosmogenic Nuclide Analysis. Ph.D. Thesis, University of Glasgow, Scotland, UK, 2014.

13. Hall, A.M.; Ebert, K.; Goodfellow, B.W.; Hättestrand, C.; Heyman, J.; Krabbendam, M.; Moon, S.; Stroeven, A.P. Past and Future Impact of Glacial Erosion in Forsmark and Uppland; Svensk Kärnbränslehantering AB: Stockholm, Sweden, 2019 ; p. 247.

14. Terry, J.; Goff, J. Megaclasts: Proposed revised nomenclature at the coarse end of the Udden-Wentworth grain-size scale for sedimentary particles. J. Sediment. Res. 2014, 84, 192-197. [CrossRef]

15. Finch, T.; Synge, F. The drifts and soils of West Clare and the adjoining parts of counties Kerry and Limerick. Ir. Geogr. 1965, 5, 161-172. [CrossRef]

16. Hall, A.M.; Whittington, G. Late Devensian glaciation of southern Caithness. Scott. J. Geol. 1989, 25, 307-324. [CrossRef]

17. Morrow, D.W. Descriptive field classification of sedimentary and diagenetic breccia fabrics in carbonate rocks. Bull. Can. Pet. Geol. 1982, 30, 227-229.

18. Woodcock, N.H.; Miller, A.V.M.; Woodhouse, C.D. Chaotic breccia zones on the Pembroke Peninsula, south Wales: Evidence for collapse into voids along dilational faults. J. Struct. Geol. 2014, 69, 91-107. [CrossRef]

19. Krüger, J.; Kjær, K.H. A data chart for field description and genetic interpretation of glacial diamicts and associated sediments ... with examples from Greenland, Iceland, and Denmark. Boreas 1999, 28, 386-402. [CrossRef]

20. Lawson, T.J. Glacial striae and former ice movement: The evidence from Assynt, Sutherland. Scott. J. Geol. 1996, $32,59-65$. [CrossRef]

21. Krabbendam, M.; Bradwell, T.; Everest, J.D.; Eyles, N. Joint-bounded crescentic scars formed by subglacial clast-bed contact forces: Implications for bedrock failure beneath glaciers. Geomorphology 2017, 290, 114-127. [CrossRef]

22. Ravier, E.; Buoncristiani, J.-F.; Menzies, J.; Guiraud, M.; Portier, E. Clastic injection dynamics during ice front oscillations: A case example from Sólheimajökull (Iceland). Sediment. Geol. 2015, 323, 92-109. [CrossRef]

23. Mccarroll, D.; Ballantyne, C.K.; Nesje, A.; Dahl, S.O. Nunataks of the last ice sheet in northwest Scotland. Boreas 1995, 24, 305-323. [CrossRef] 
24. Lesemann, J.-E.; Alsop, G.I.; Piotrowski, J.A. Incremental subglacial meltwater sediment deposition and deformation associated with repeated ice-bed decoupling: A case study from the Island of Funen, Denmark. Quat. Sci. Rev. 2010, 29, 3212-3229. [CrossRef]

25. Rothlisberger, H.; Iken, A. Plucking as an effect of water-pressure variations at the glacier bed. Ann. Glaciol. 1981, 2, 57-62. [CrossRef]

26. Harper, J.T.; Humphrey, N.F.; Pfeffer, W.T.; Lazar, B. Two modes of accelerated glacier sliding related to water. Geophys. Res. Lett. 2007, 34. [CrossRef]

27. Yeo, I.; De Freitas, M.; Zimmerman, R. Effect of shear displacement on the aperture and permeability of a rock fracture. Int. J. Rock Mech. Min. Sci. 1998, 35, 1051-1070. [CrossRef]

28. Boulton, G.S.; Hagdorn, M. Glaciology of the British Isles Ice Sheet during the last glacial cycle: Form, flow, streams and lobes. Quat. Sci. Rev. 2006, 25, 3359-3390. [CrossRef]

29. Boulton, G.S.; Caban, P. Groundwater flow beneath ice sheets: Part II-its impact on glacier tectonic structures and moraine formation. Quat. Sci. Rev. 1995, 14, 563-587. [CrossRef]

30. Alley, R.; Cuffey, K.; Zoet, L. Glacial erosion: Status and outlook. Ann. Glaciol. 2019, 60, 1-13. [CrossRef]

31. Glasser, N.F.; Roman, M.; Holt, T.O.; Žebre, M.; Patton, H.; Hubbard, A.L. Modification of bedrock surfaces by glacial abrasion and quarrying: Evidence from North Wales. Geomorphology 2020, 365, 107283. [CrossRef]

32. Hallet, B. Glacial abrasion and sliding: Their dependence on the debris concentration in basal ice. Ann. Glaciol. 1981, 2, 23-28. [CrossRef]

33. Migoń, P. Sandstone geomorphology-recent advances. Geomorphology 2020, 373, 107484. [CrossRef]

34. Merritt, J.W.; Coope, G.R.; Taylor, B.J.; Walker, M.J.C. Late Devensian organic deposits beneath till in the Teith Valley, Perthshire. Scott. J. Geol. 1990, 26, 15-24. [CrossRef]

35. Evans, D.J.; Dinnage, M.; Roberts, D.H. Glacial geomorphology of Teesdale, northern Pennines, England: Implications for upland styles of ice stream operation and deglaciation in the British-Irish Ice Sheet. Proc. Geol. Assoc. 2018, 129, 697-735. [CrossRef]

36. Harris, C. Glacially deformed bedrock at Wylfa Head, Anglesey, North Wales. In Engineering Geology Special Publications; Geological Society: London, UK, 1991; Volume 7, pp. 135-142. [CrossRef]

37. Evans, D.J.A.; Rea, B.R.; Benn, D.I. Subglacial deformation and bedrock plucking in areas of hard bedrock. Glacial Geol. Geomorphol. 1998, 1, 1-25.

38. Phillips, E.; Everest, J.; Reeves, H. Micromorphological evidence for subglacial multiphase sedimentation and deformation during overpressurized fluid flow associated with hydrofracturing. Boreas 2013, 42, 395-427. [CrossRef]

39. Phillips, E.; Auton, C. Microtextural analysis of a glacially 'deformed' bedrock: Implications for inheritance of preferred clast orientations in diamictons. J. Quat. Sci. 2008, 23, 229-240. [CrossRef]

40. Croot, D.G.; Sims, P.C. Early stages of till genesis: An example from Fanore, County Clare, Ireland. Boreas 1996, 25, 37-46. [CrossRef]

41. Hiemstra, J.F.; Evans, D.J.A.; Cofaigh, C.Ó. The role of glacitectonic rafting and comminution in the production of subglacial tills: Examples from southwest Ireland and Antarctica. Boreas 2007, 36, 386-399. [CrossRef]

42. Vaughan-Hirsch, D. Large-scale thrusting and glacitectonic rafting of limestone bedrock during active ice retreat: An example from Killala Bay, Co. Mayo, Republic of Ireland. Quat. Int. 2012, 279-280, 516. [CrossRef]

43. Phillips, E.; Lee, J.R.; Riding, J.B.; Kendall, R.; Hughes, L. Periglacial disruption and subsequent glacitectonic deformation of bedrock: An example from Anglesey, North Wales, UK. Proc. Geol. Assoc. 2013, 124, 802-817. [CrossRef]

44. Davies, B.J.; Roberts, D.H.; Ó Cofaigh, C.; Bridgland, D.R.; Riding, J.B.; Phillips, E.R.; Teasdale, D.A. Interlobate ice-sheet dynamics during the last glacial maximum at Whitburn Bay, County Durham, England. Boreas 2009, 38, 555-578. [CrossRef]

45. Różycki, S.Z.; Lamparski, Z. Exaration phenomena at the terminal icesheet parts of the Middle-Polish Glaciation along the northern slopes of the Central Polish Uplands. Acta Geol. Pol. 1982, 32, 207-216.

46. Eyles, N.; Doughty, M. Glacially-streamlined hard and soft beds of the paleo-Ontario ice stream in Southern Ontario and New York state. Sediment. Geol. 2016, 338, 51-71. [CrossRef]

47. Schroeder, J.; Beaupré, M.; Cloutier, M. Ice-push caves in platform limestones of the Montréal area. Can. J. Earth Sci. 1986, 23, 1842-1851. [CrossRef]

48. Schroeder, J.; Beaupré, M.; Caron, D. Glacitectonic caves in the St. Lawrence lowlands of Québec. In Landscapes and Landforms of Eastern Canada; Springer: Berlin, Germany, 2020; pp. 509-523.

49. Broughton, P.L. Subglacial blowouts in western Canada: Insights into extreme meltwater pressures and hydrofracturing. Boreas 2018, 47, 326-346. [CrossRef]

50. Broster, B.; Dreimanis, A.; White, J. A sequence of glacial deformation, erosion, and deposition at the ice-rock interface during the last glaciation: Cranbrook, British Columbia, Canada. J. Glaciol. 1979, 23, 283-295. [CrossRef]

51. Aber, J.S.; Croot, D.G.; Fenton, M.M. Hill-Hole Pair. In Glaciotectonic Landforms and Structures; Springer: Berlin/Heidelberg, Germany, 1989; pp. 13-28.

52. Evans, D.J.A.; Phillips, E.R.; Hiemstra, J.F.; Auton, C.A. Subglacial till: Formation, sedimentary characteristics and classification. Earth-Sci. Rev. 2006, 78, 115-176. [CrossRef]

53. Lee, J.R.; Phillips, E. Glacitectonics-A key approach to examining ice dynamics, substrate rheology and ice-bed coupling. Proc. Geol. Assoc. 2013, 124, 731-737. [CrossRef] 
54. Phillips, E.R. Chapter 13-Glacitectonics. In Past Glacial Environments, 2nd ed.; Menzies, J., van der Meer, J.J.M., Eds.; Elsevier: Amsterdam, The Netherlands, 2018; pp. 467-502. [CrossRef]

55. Knight, J. Glacitectonic sedimentary and hydraulic processes at an oscillating ice margin. Proc. Geol. Assoc. 2012, 123, 714-727. [CrossRef]

56. Sigfúsdóttir, T.; Phillips, E.; Benediktsson, Í.Ö. Micromorphological evidence for the role of pressurised water in the formation of large-scale thrust-block moraines in Melasveit, western Iceland. Quat. Res. 2020, 93, 88-109. [CrossRef]

57. Phillips, E.; Lee, J.R. Development of a subglacial drainage system and its effect on glacitectonism within the polydeformed Middle Pleistocene (Anglian) glacigenic sequence of north Norfolk, Eastern England. Proc. Geol. Assoc. 2013, 124, 855-875. [CrossRef]

58. Warbritton, M.; Iverson, N.R.; Lagroix, F.; Schomacker, A. Strain patterns in glacitectonically thrusted sediments and conditions during thrusting. J. Struct. Geol. 2020, 137, 104064. [CrossRef]

59. Aber, J.; Lundqvist, J. Glaciotectonic structures in central Sweden and their significance for glacial theory. Géographie Phys. Quat. 1988, 42, 315-323. [CrossRef]

60. Rattas, M.; Kalm, V. Glaciotectonic deformation patterns in Estonia. Geol. Q. 2004, 48, 15-22.

61. Hall, A.M.; van Boeckel, M. Origin of the Baltic Sea basin by Pleistocene glacial erosion. GFF 2020, 142, 237-252. [CrossRef]

62. Larson, G.; Schaetzl, R. Origin and evolution of the Great Lakes. J. Great Lakes Res. 2001, 27, 518-546. [CrossRef]

63. Shulmeister, J. A conceptual model for the deposition of the Dummer Moraine, Southern Ontario. Geomorphology 1989, 2, 385-392. [CrossRef]

64. Bukhari, S.; Eyles, N.; Sookhan, S.; Mulligan, R.; Paulen, R.; Krabbendam, M.; Putkinen, N. Regional subglacial quarrying and abrasion below hard-bedded palaeo-ice streams crossing the Shield-Palaeozoic boundary of central Canada: The importance of substrate control. Boreas 2021. [CrossRef] 